\title{
Effect of Nitrogen Fertilizer Rates and Plant Density on Straw, Fiber Yield and
} Anatomical Manifestations of Some Flax Cultivars

\author{
Khaled S. S. El-Shimy*; Gaber Y. M. Hammam**; Salah A. H. Allam**; \\ Saber H. A. Mostafa* and El-Saeed M. M. El-Gedwy *** \\ *Fiber Crops Research Section, Field Crops Research Institute, Agricultural Research Center, Giza, Egypt. \\ **Agronomy Department, Faculty of Agriculture, Benha University, Egypt. \\ Corresponding author: alsaeed.algedwy@fagr.bu.edu.eg
}

\begin{abstract}
Two field experiments were carried out at the Experimental Farm at Gemmeiza Agriculture Research Station, Agricultural Research Center, Egypt, during two successive winter growing seasons of 2018/2019 and 2019/2020 to study the response of three flax cultivars, i.e. Sakha 3, Giza 11 and Giza 12 to three nitrogen fertilizer rates (30, 50 and $70 \mathrm{~kg} \mathrm{~N} / \mathrm{fed})$ and three plant densities (1500, 2000 and $\left.2500 \mathrm{seeds} / \mathrm{m}^{2}\right)$ and their effect on straw and fiber yield and its related traits as well as anatomical manifestations for flax stem at middle region. The experimental design was laid out using split-split plot design in four replications. Flax cultivars were distributed in the main plots, whereas nitrogen fertilizer rates were arranged at random in sub-plots and plant densities treatments were assigned at random in sub-sub plots. The sub-sub plot area was $9 \mathrm{~m}^{2}$. Sakha 3 cultivar significantly produced the maximum total plant height, technical stem length, total fiber percentage, fiber yield/plant, fiber yield/fed, fiber length and fiber fineness in both seasons. Meanwhile, the highest No. of basal branches/plant, straw yield/plant and straw yield/fed in both seasons were recorded with Giza 12 cultivar. Meanwhile, Giza 11 cultivar gave the thickness stem diameter in both seasons. Increasing nitrogen fertilizer rates from 30 to $70 \mathrm{~kg} \mathrm{~N} /$ fed caused significant increases in all straw and fiber yield and its related traits of flax, except fiber fineness was significantly decreased with increasing nitrogen rates in both seasons. Increasing plant densities from 1500 to 2500 seeds $/ \mathrm{m}^{2}$ caused markedly increment in total plant height, technical stem length, straw yield/fed, total fiber percentage, fiber yield/fed, fiber length and fiber fineness during both seasons. On the other hand, No. of basal branches/plant, stem diameter, straw yield/plant and fiber yield/plant were significantly decreased by increasing plant densities during both seasons. The first order interactions between treatments Sakha 3 X $70 \mathrm{~kg} \mathrm{~N} / \mathrm{fed}$, Sakha 3 X $2500 \mathrm{seeds} / \mathrm{m}^{2}$ and $70 \mathrm{~kg} \mathrm{~N} / \mathrm{fed}$ X $2500 \mathrm{seeds} / \mathrm{m}^{2}$ as well as the second order interaction between treatments Sakha 3 X $70 \mathrm{~kg} \mathrm{~N} /$ fed X 2500 seeds $/ \mathrm{m}^{2}$ were significantly recorded the highest total plant height, technical stem length, fiber yield/fed and fiber length as compared with the others interactions in both seasons. While, the maximum fiber yield/fed were recorded from the first order interactions between treatments Sakha 3 X $70 \mathrm{~kg} \mathrm{~N} / \mathrm{fed}$, Sakha 3 X $2500 \mathrm{seeds} / \mathrm{m}^{2}$ and $70 \mathrm{~kg} \mathrm{~N} / \mathrm{fed}$ X $2500 \mathrm{seeds} / \mathrm{m}^{2}$ as well as the second order interaction between treatments Sakha 3 X $70 \mathrm{~kg}$ N/fed X $2500 \mathrm{seeds} / \mathrm{m}^{2}$. Data illustrated an increase in each of total cross section area, cortex area, fiber area, xylem area, fiber index per plant, cortex $\%$ and xylem \% in all flax cultivars under study (Sakha 3, Giza 11 and Giza 12) as affected by fertilized flax plants with $70 \mathrm{~kg} \mathrm{~N} / \mathrm{fed}$ and plant density at $1500 \mathrm{seeds} / \mathrm{m}^{2}$. It could be concluded that Sakha 3 cultivar and fertilizing by 70 $\mathrm{kg} \mathrm{N} /$ fed with plant density of $2500 \mathrm{seeds} / \mathrm{m}^{2}$ to maximizing fiber yield/fed and quality.
\end{abstract}

Keywords: flax, cultivars, Nitrogen fertilizer, plant densities, straw yield, fiber yield, anatomical manifestations.

\section{Introduction}

In Egypt, Flax (Linum usitatissimum L.) ranked second after cotton as a fiber crop regarding the cultivated area and industry importance. The fibers, which extracted from flax stem by retting process is a good row material for textile in addition to the oil obtained from seeds. Therefore, many industries had been established on flax fiber and seeds. Fresh linseed oil is used as human food and after boiling and treated chemically used as painting ink and varnish industries. Moreover, linseed cake is a valuable protein source to poultry and ruminants. Recently, the cultivated area by flax in Egypt tended to decrease in the valley lands due to great competition with other major winter crops. Flax yield potential could be sustained through the use of high yielding varieties with application of the best agronomic practices such as nitrogen fertilizer rates and plant densities.

Varietal differences among flax cultivars have been reported by many investigators as Omar and Ash-Shormillesy 2006; Ahmed 2010; Abd ElMohsen et al. 2013; Abd Eldaiem 2015; Andruszczak et al. 2015; El-Refaey et al. 2015; ElBorhamy 2016; Ibrahim et al. 2016; Gupta et al. 2017; Fila et al. 2018; Abdel-Kader and Mousa 2019; Emam 2019 and Emam 2020 they found that significant differences among the test cultivars in straw and fiber yield/fed and its related traits.

Determination of the required rate of nitrogen fertilizer of flax plants is the main important practices 
of great contribution for the highest production and better quality, as well as nitrogen is a key element for flax productivity. Several investigations reported that increasing nitrogen fertilizer rates caused significant increases in flax straw and fiber yield/fed and its related traits. On the other hand, fiber fineness was significantly decreased Omar and Ash-Shormillesy 2006; Ahmed 2010; El-Nagdy et al. 2010; Andruszczak et al. 2015; El-Refaey et al. 2015; ElBorhamy 2016; Ibrahim et al. 2016; El-Shimy et al. 2017; Gupta et al. 2017; El-Gedwy et al. 2018; Abdel-Kader and Mousa 2019 and Emam 2019.

The effect of plant density on straw and fiber yield as well as their quality was studied by many investigators as, Omar and Ash-Shormillesy 2006; Ahmed 2010; Abd El-Mohsen et al. 2013; Abd Eldaiem 2015; Andruszczak et al. 2015; ElBorhamy 2016; Fila et al. 2018; Ganvit et al. 2019 and Teshome et al. 2020, who found significant increase in total plant height, technical stem length, straw yield/fed, total fiber percentage, fiber yield/fed, fiber length and fiber fineness, but significant decreased in No. of basal branches/plant, stem diameter, straw yield/plant and fiber yield/plant with increasing plant density.

Regarding anatomical study, varietal differences had been found in all anatomical tissues per cross section for flax stem at middle region of technical length, i.e. total cross section, cortex, fiber, xylem and pith areas in addition to fiber index (El-Shimy $\boldsymbol{e t}$ al. 1993 and 2019). Nitrogen fertilizer affected anatomical manifestations as reported by El-Shimy et al. 1993; El-Nagdy et al. 2010 and El-Gedwy $e t$ al. 2018, who illustrated that gradual increment for all anatomical characters due to increasing nitrogen fertilizer rates except with pith area which decreased in this case. Increase plant density caused somewhat decrements in anatomical tissue area in the cross section for flax stem, while more seeding rate (plant density) achieved more technical stem length (searching for light) which compensate the little tissues area per cross section and increase fiber index (El-Shimy et al. 1993).

The aim of this investigation was designed to study the effect of nitrogen fertilizer rates and plant densities on straw and fiber yield and its components of flax cultivars, in addition to their quality as well as anatomical manifestations for flax stem at middle region of technical length in farm at El-Gemmeiza Research Station, Gharbia Governorate, Egypt.

\section{Materials and Methods:}

Two field experiments were conducted at the Experimental Farm at Gemmeiza Agriculture Research Station, Agricultural Research Center, Egypt, during two successive winter growing seasons of 2018/2019 and 2019/2020 to study the response of three flax cultivars to three nitrogen fertilizer rates (30, 50 and $70 \mathrm{~kg} \mathrm{~N} /$ fed) with three plant densities;
1500, 2000 and 2500 seeds $/ \mathrm{m}^{2}$ and their effect on straw and fiber yield and its related traits.

The cultivar seeds were obtained from Fiber Crops Research Section, Field Crops Research Institute, Agricultural Research Center, Egypt and its pedigree was shown in Table 1.

Table 1: Type and pedigree of studied flax cultivars.

\begin{tabular}{ccc}
\hline Flax cultivar & Type & Pedigree \\
\hline Sakha 3 & Fiber & I.2596 x Belinka \\
Giza 11 & dual purpose & Giza $8 \times$ S.2419 \\
Giza 12 & dual purpose & S.2419 x S.148/6/1 \\
\hline
\end{tabular}

Nitrogen fertilizer was applied in form of urea (46 $\% \mathrm{~N}$ ), and divided into two equal parts which applied before the first and second irrigations in both seasons.

The seeding rates $(\mathrm{kg} / \mathrm{fed})$ from plant densities treatments (No. of seeds $/ \mathrm{m}^{2}$ ) for the studied flax cultivars as shown in Table 2.

Table 2. Planting density of flax cultivars (seeds $/ \mathrm{m}^{2}$ ) and their corresponding number of seeds per $3 \mathrm{~m}$ long of row and seeding rates $(\mathrm{kg} / \mathrm{fed})$.

\begin{tabular}{cccc}
\hline Flax cultivar & $\begin{array}{c}\text { Plant density } \\
(\mathbf{N o .} \text { of } \\
\text { seeds/m } \mathbf{2})\end{array}$ & $\begin{array}{c}\text { No. of seeds } \\
\text { per } \mathbf{3 ~ m} \\
\text { long of row }\end{array}$ & $\begin{array}{c}\text { Seeding rates } \\
(\mathbf{k g} / \mathbf{f e d}) \mathbf{c}\end{array}$ \\
\hline \multirow{4}{*}{ Sakha 3 } & $\mathbf{1 5 0 0}$ & 675 & 33.08 \\
& $\mathbf{2 0 0 0}$ & 900 & 44.10 \\
& $\mathbf{2 5 0 0}$ & 1125 & 55.13 \\
\cline { 2 - 4 } Giza 11 & $\mathbf{1 5 0 0}$ & 675 & 48.83 \\
& $\mathbf{2 0 0 0}$ & 900 & 65.10 \\
& $\mathbf{2 5 0 0}$ & 1125 & 81.38 \\
\cline { 2 - 4 } Giza 12 & $\mathbf{1 5 0 0}$ & 675 & 46.31 \\
& $\mathbf{2 0 0 0}$ & 900 & 61.74 \\
& $\mathbf{2 5 0 0}$ & 1125 & 77.18 \\
\hline
\end{tabular}

\section{Soil analysis:}

Soil texture of the experimental site was silty clay loam texture with $\mathrm{pH}$ nearly of 8.0. Soil samples were taken before sowing of crop to depth of 0-30 cm for chemical and mechanical properties analysis of the experimental soil were determined according to the standard procedures described by Rowell (1995) and represented in Table 3 in each of two growing seasons.

The preceding summer crop in two seasons was rice (Oryza sativa, L.). The experimental design was laid out using split-split plot design in four replications. Each of the three flax cultivars were distributed in the main plots, whereas the three nitrogen fertilizer rates were arranged at random in sub-plots and the three plant densities treatments were assigned at random in sub-sub plots. The experimental unit comprised $9 \mathrm{~m}^{2}$ with $3 \mathrm{~m}$ long and $3 \mathrm{~m}$ width, forming 20 rows of $15 \mathrm{~cm}$ between rows. Flax seeds were sown on November $1^{\text {th }}$ and $11^{\text {th }}$ in the first season $(2018 / 2019)$ and the second season (2019/2020), respectively. Phosphorous fertilizer was applied in form of calcium super phosphate $(12.5 \%$ 
$\mathrm{P}_{2} \mathrm{O}_{5}$ ) at a level of $100 \mathrm{~kg} / \mathrm{fed}$ during soil preparation in each season. The others recommended agronomic practices of growing flax were applied in the manner prevailing in the region were practiced.

Table 3. Chemical and mechanical properties of the experimental soil units at flax planting during 2018/2019 and 2019/2020 seasons.

\begin{tabular}{lcc}
\hline \multirow{2}{*}{ Properties } & \multicolumn{2}{c}{ Season } \\
\cline { 2 - 3 } Chemical analysis: & $\mathbf{2 0 1 8 / 2 0 1 9}$ & $\mathbf{2 0 1 9 / 2 0 2 0}$ \\
\hline E.C. (ds/m) & 3.39 & 3.42 \\
pH $(1: 2.5)$ & 7.95 & 7.92 \\
Ca Co3\% & 1.94 & 2.15 \\
O.M \% & 2.06 & 1.92 \\
N \% (total) & 0.130 & 0.111 \\
P \% (total) & 0.093 & 0.085 \\
K \% (total) & 0.125 & 0.097 \\
N (ppm) (available) & 29.55 & 24.43 \\
P (ppm) (available) & 10.25 & 9.21 \\
K (ppm) (available) & 133.45 & 111.05 \\
\hline Mechanical analysis: & \multicolumn{2}{|}{} \\
\hline Course sand \% & 4.55 & 5.22 \\
Find sand \% & 10.33 & 9.89 \\
Silt \% & 47.56 & 45.81 \\
Clay \% & 37.56 & 39.08 \\
\hline Texture grade & Silty Clay Loam
\end{tabular}

Texture grade

Silty Clay Loam

\section{Studied traits:}

At maturity, about 150 days from sowing date, ten guarded plants were taken randomly from each subsub plot for recording straw plant traits. Straw and fiber yield $(\mathrm{kg} / \mathrm{fed})$ were estimated according to yield from three meter square of each sub-sub plot. After harvesting and removing the capsules from plants in one meter square of each sub-sub plot, retting process took place at Fiber Crops Research Section, Gemmeiza Agriculture Research Station, Gharbia Governorate, Agricultural Research Center, Egypt. Straw from plants in one meter square of each subsub plot was arranged in bundles and put in retting basins and soaked in water for about 12 hours. After soaking, the water was changed to leach out all the soluble materials. Retting interval was about one week in summer season. The degree of water temperature during retting process ranged from 28 to $32^{\circ} \mathrm{C}$ and the acidity was $\mathrm{pH}$ 6-7. The retted straw was washed with water and finally dried in open air. Thus, the fibers were easily extracted from the woody part of stem.

\section{A- Straw yield and its related traits:}

Total plant height $(\mathrm{cm})$, technical stem length of the main stem $(\mathrm{cm})$, No. of basal branches/plant, stem diameter $(\mathrm{mm})$, straw yield/plant $(\mathrm{g})$ and straw yield/fed $(\mathrm{kg})$.

\section{B- Fiber yield and its related traits:}

Total fiber percentage (\%), fiber yield/plant (g), fiber yield/fed $(\mathrm{kg})$, fiber length $(\mathrm{cm})$ of the main stem and fiber fineness $(\mathrm{Nm})$ determined using
Radwan and Momtaz (1966) methods according to the following equation: $\mathbf{N m}=(\mathbf{N} \times \mathbf{L}) / \mathbf{W}$.

Where,

$\mathrm{Nm}=$ Metrical number.

$\mathrm{N}=$ number of fibers (20 fibers and the length for each one equal $10 \mathrm{~cm}$ ).

$\mathrm{L}=$ Length of fibers in $\mathrm{mm}(2000 \mathrm{~mm})$.

$\mathrm{W}=$ Weight of fibers in $\mathrm{mg}$.

\section{C- Anatomical manifestations:}

In the second season (2019/2020), at maturity stage, while plants were standing in the field, samples of five plants were chosen from the main stems at middle region. These samples were killed and fixed for 36 hours in F.A.A. "Formalin, Acetic acid and Alcohol Ethyle as -follow: "200 ccs. of 50\% alcohol, $13 \mathrm{ccs}$. Formalin, $50 \mathrm{ccs}$, Acetic acid. This solution (F.A.A.) can be used as Killing, fixing, and for preservation for some time. After fixation, samples were washed in distilled water and then dehydrated in the following steps; $15 \%, 30 \%, 45 \%, 60 \%, 70 \%$, $80 \%, 95 \%$ and $100 \%$ of alcohol. Samples were kept in each solution for Five hours, xylol as a clearing agent rendered the specimen transparent. It replaced the dehydrating agent with a solvent of paraffin. The specimens were passed through a series of gradual increasing strength of "xylol", and absolute alcohol, for each grade five hours. Embedding was done in paraffin wax of 52c melting point. Samples were microtomed at 25 microns on a sliding microtome. The slides were smeared with small quantity of Mayer Albumen before mounting the ribbon. Sections were stained in $0.5 \%$ safranin solution which stained the nucleus and Lignified tissues with red tan. Tissues were counter stained with $1 \%$ light green dissolved in clove oil which gave the cytoplasm and cell wall a green color. Measurements of the total cross section, cortex, fiber, xylem and pith tissues were done by Visopan apparotus, drawings at magnification of 50x. The above tissues were measured by means of planimeter, and then calculated to its absolute amount to the nearest $\mathrm{mm}$, using method Sass (1951) for cutting and Johanson (1940) for pigmenting method.

$\mathrm{C}_{1}$-Tissues area: total cross section area $\left(\mathrm{mm}^{2}\right)$, cortex area $\left(\mathrm{mm}^{2}\right)$, fiber area $\left(\mathrm{mm}^{2}\right)$, xylem area $\left(\mathrm{mm}^{2}\right)$ and pith area $\left(\mathrm{mm}^{2}\right)$ in addition to fiber index $\left(\mathrm{mm}^{3}\right)$ calculated from the product of fiber area $\left(\mathrm{mm}^{2}\right)$ per cross section $\mathrm{X}$ technical stem length $(\mathrm{mm})$, this measurement represented the fiber which flax plant contain in volume.

$\mathbf{C}_{2}$-Percentage of different tissues per cross section: cortex $\%$, fiber $\%$, xylem $\%$ and pith $\%$.

\section{Statistical analysis:}

The analysis of variance was carried out according to the procedure described by Gomez and Gomez (1984). Data were statistically analyzed according to using the MSTAT-C Statistical Software Package (Freed, 1991). Where the F-test showed significant differences among means L. S. D. test at 0.05 level was used to compare between means. 


\section{Results and Discussion:}

\section{A- Straw yield and its related traits:}

\section{1) Effect of flax cultivars:}

Results presented in Table 4 showed that all straw yield and its related traits under study were differed significantly among the three flax cultivars during 2018/2019 and 2019/2020 seasons. The differences between flax cultivars Giza 11 and Giza 12 did not reach the level of significance in total plant height, technical stem length, straw yield/plant and straw yield/fed. The maximum total plant height and technical stem length were achieved by Sakha 3 during both seasons. Sakha 3 cultivar increased total plant height by 11.61 and $14.44 \%$ in $2018 / 2019$ season, corresponding to 9.56 and $11.78 \%$ in 2019/2020season, over total plant height of Giza 12 and Giza 11 cultivars, respectively. Results may reveal the superiority of Giza 12 cultivar in No. of basal branches/plant, straw yield/plant and straw yield/fed in two seasons. Giza 11 and Giza 12 cultivars significantly increased straw yield/fed by 10.58 and $14.49 \%$ in the first season, and by 13.23 and $16.75 \%$ in second season, respectively compared to flax cultivar of Sakha 3. Giza 11 cultivar gave the thickness stem diameter in both seasons. Giza 12 and Giza 11 cultivars significantly increased stem diameter by 34.37 and $50.38 \%$ in the first season, respectively, and by 34.44 and $43.68 \%$ in the second season, respectively as compared to stem diameter of Sakha 3 cultivar. These differences in straw yield and its related traits of flax cultivars may be due to the genetic differences between flax cultivar of Sakha 3 (fiber flax type) and flax cultivars Giza 11 and Giza 12 (dual purpose type). As well as, It could be concluded that Giza 12 surpassed the other two flax cultivars to increase straw yield/fed may be due to more likely attributed to the increases in straw yield/plant and No. of basal branches/plant. These results in good accordance with those reported by Omar and Ash-Shormillesy 2006; Ahmed 2010; Abd El-Mohsen et al. 2013; Abd Eldaiem 2015; Andruszczak et al. 2015; El-Refaey et al. 2015; El-Borhamy 2016; Ibrahim et al. 2016; Gupta et al. 2017; Fila et al. 2018; Abdel-Kader and Mousa 2019; Emam 2019 and Emam 2020, showed that cultivars markedly varied for all straw yield and its related traits of flax plants.

Table 4. Mean values of straw yield and its related traits of flax cultivars during 2018/2019 (1 $\left.{ }^{\text {st }}\right)$ and 2019/2020 $\left(2^{\text {nd }}\right)$ seasons.

\begin{tabular}{|c|c|c|c|c|c|c|c|c|c|c|c|c|}
\hline \multirow[t]{2}{*}{ Flax cultivar } & \multicolumn{2}{|c|}{$\begin{array}{c}\text { Total plant } \\
\text { height } \\
(\mathbf{c m})\end{array}$} & \multicolumn{2}{|c|}{$\begin{array}{l}\text { Technical stem } \\
\text { length } \\
\text { (cm) }\end{array}$} & \multicolumn{2}{|c|}{$\begin{array}{c}\text { No. of basal } \\
\text { branches } \\
\text { /plant }\end{array}$} & \multicolumn{2}{|c|}{$\begin{array}{l}\text { Stem diameter } \\
\qquad(\mathbf{m m})\end{array}$} & \multicolumn{2}{|c|}{$\begin{array}{c}\text { Straw } \\
\text { yield/plant (g) }\end{array}$} & \multicolumn{2}{|c|}{$\begin{array}{c}\text { Straw yield/fed } \\
(\mathbf{k g})\end{array}$} \\
\hline & $1^{\text {st }}$ & $2^{\text {nd }}$ & $1^{\text {st }}$ & $2^{\text {nd }}$ & $1^{\text {st }}$ & $2^{\text {nd }}$ & $1^{\text {st }}$ & $2^{\text {nd }}$ & $1^{\text {st }}$ & $2^{\text {nd }}$ & $1^{\text {st }}$ & $2^{\text {nd }}$ \\
\hline & 3. & 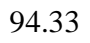 & 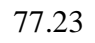 & 700 & 528 & 1.354 & 2 & 4 & 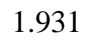 & 3 & $T$ & 33 \\
\hline & 0.28 & 9 & 24 & 66 & 2.077 & 1. & 1.98 & 1.773 & 2. & 9 & 396 & 3795.03 \\
\hline Giza & 92.57 & 86.10 & 70.99 & 67.28 & 2.709 & 2.491 & 1 . & 1 & 2. & 5 & 41 & 3.28 \\
\hline L.S.D. at $5 \%$ & 15 & 3.56 & 2.98 & 2.67 & 0.098 & 0.087 & 0.093 & 0.000 & 0.111 & 0.107 & 348.62 & 315.45 \\
\hline
\end{tabular}

\section{2) Effect of nitrogen fertilizer rates:}

Results in Table 5 revealed that increasing nitrogen fertilizer rates from 30 up to $70 \mathrm{~kg} \mathrm{~N} / \mathrm{fed}$ caused significant increments in all flax traits in both seasons. While, No. of basal branches/plant was not significantly affected by nitrogen fertilizer rates in both seasons. But, the differences between nitrogen fertilizer rates of 50 and $70 \mathrm{~kg} \mathrm{~N} /$ fed on technical stem length and stem diameter as well as among 30 and $50 \mathrm{~kg} \mathrm{~N} / \mathrm{fed}$ on stem diameter were not significant in both seasons. Flax plants which fertilized by $70 \mathrm{~kg} \mathrm{~N} /$ fed produced significantly the maximum total plant height, technical stem length, stem diameter, straw yield/plant and straw yield/fed in both seasons. On the other hand, the lowest total plant height, technical stem length, stem diameter, straw yield/plant and straw yield/fed in two seasons were obtained from flax planting received $30 \mathrm{~kg}$ $\mathrm{N} / \mathrm{fed}$. The superiority ratios in the first season between the highest nitrogen rate $(70 \mathrm{~kg} \mathrm{~N} / \mathrm{fed})$ and each of 50 and $30 \mathrm{~kg} \mathrm{~N} /$ fed were 4.08 and $9.70 \%$ for total plant height; 3.55 and $9.36 \%$ for technical stem length; 2.47 and $6.49 \%$ for stem diameter; 11.40 and
$31.49 \%$ for straw yield/plant in addition to 11.77 and $33.04 \%$ for straw yield/fed, respectively. The excess ratios in the second season when flax received $70 \mathrm{~kg}$ $\mathrm{N} /$ fed over each of 50 and $30 \mathrm{~kg} \mathrm{~N} /$ fed were 3.96 and $9.59 \%$ for total plant height; 3.53 and $9.14 \%$ for technical stem length; 2.94 and $7.91 \%$ for stem diameter 8.95 and $30.87 \%$ for straw yield/plant in addition to 8.38 and $32.02 \%$ for straw yield/fed, respectively. The increase in growth traits associated with increasing nitrogen fertilization rates may be attributed to the role of nitrogen in enhancement meristematic activity and cell division, which caused increases in number and size of cells in flax stem. Also, the increases in straw yield/plant and straw yield/fed with increase in nitrogen fertilizer rates may be attributed to the increases in total plant height, technical stem length and stem diameter of flax plant. Many investigators came out with similar results as Ahmed 2010; El-Nagdy et al. 2010; Andruszczak et al. 2015; El-Refaey et al. 2015; El-Borhamy 2016; Ibrahim et al. 2016; El-Shimy et al. 2017; Gupta et al. 2017; El-Gedwy et al. 2018; AbdelKader and Mousa 2019 and Emam 2019. 
Table 5. straw yield and its related traits of flax as affected by nitrogen fertilizer rates during 2018/2019 (1 $\left.{ }^{\text {st }}\right)$ and $2019 / 2020\left(2^{\text {nd }}\right)$ seasons.

\begin{tabular}{|c|c|c|c|c|c|c|c|c|c|c|c|c|}
\hline \multirow[t]{2}{*}{$\begin{array}{c}\text { Nitrogen rate } \\
\text { (kg N/fed) }\end{array}$} & \multicolumn{2}{|c|}{$\begin{array}{c}\text { Total plant } \\
\text { height } \\
(\mathbf{c m})\end{array}$} & \multicolumn{2}{|c|}{$\begin{array}{c}\text { Technical stem } \\
\text { length } \\
\text { (cm) }\end{array}$} & \multicolumn{2}{|c|}{$\begin{array}{c}\text { No. of basal } \\
\text { branches } \\
\text { /plant }\end{array}$} & \multicolumn{2}{|c|}{$\begin{array}{l}\text { Stem diameter } \\
(\mathbf{m m})\end{array}$} & \multicolumn{2}{|c|}{$\begin{array}{l}\text { Straw yield/ } \\
\text { plant (g) }\end{array}$} & \multicolumn{2}{|c|}{$\begin{array}{c}\text { Straw yield/fed } \\
(\mathrm{kg})\end{array}$} \\
\hline & $1^{\text {st }}$ & $2^{\text {nd }}$ & $1^{\text {st }}$ & $2^{\text {nd }}$ & $1^{\text {st }}$ & $2^{\text {nd }}$ & 1st & & $1^{\text {st }}$ & nd & $1^{\text {st }}$ & $2^{\text {nd }}$ \\
\hline$\sqrt{2}$ & $\overline{8}$ & 407 & 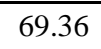 & & 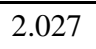 & & 102 & 1400 & 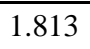 & 1.720 & 7.03 & 287 \\
\hline 50 & 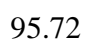 & & & & 10 & & & & & U & 39 & .69 \\
\hline 70 & 99.63 & 92.13 & 75.85 & 70.72 & 2.187 & 2.017 & 1. & 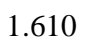 & 2. & 1 & 4399.69 & 4126.64 \\
\hline L.S.D. at $5 \%$ & 2.99 & 2.88 & 2.85 & 2.64 & N.S. & N.S. & 0.081 & 0.075 & 0.097 & 0.093 & 315.27 & 288.69 \\
\hline
\end{tabular}

\section{3) Effect of plant densities treatments:}

Results presented in Table 6 revealed that the differences between the three plant densities were significant on all straw yield and its related traits during two seasons. Flax planting at highest plant density (2500 flax seeds $/ \mathrm{m}^{2}$ ) markedly gave the maximum total plant height, technical stem length and straw yield/fed in both seasons. On the other hand, the lowest total plant height, technical stem length and straw yield/fed in both seasons were recorded from flax planting under the lowest plant density (1500 seeds $\left./ \mathrm{m}^{2}\right)$. Increasing plant density from 1500 to 2000 and 2500 seeds $/ \mathrm{m}^{2}$ significantly increased straw yield/fed by 17.36 and $28.03 \%$ respectively, in the first season. The corresponding increases were 18.71 and $29.66 \%$ in the second season for the respective densities. The increases in total plant height and technical stem length by increasing plant densities is mainly due to the increased intra-specific competition among flax plants for light and decrease in light penetration, interception and photosynthetic efficiency at higher densities as well as higher dense of plants excessive shade exist which help to produce more content of gibberellin in tissues and consequently higher plants formed. Such increase in straw yield could be due to the increase in total plant height and technical stem length as well as No. of flax plants $/ \mathrm{m}^{2}$ due to increasing plant densities. These results are in harmony with those reported by Abd El-Mohsen $\boldsymbol{e t}$ al. 2013; Andruszczak et al. 2015; Ganvit et al. 2019 and Teshome et al. 2020. The greatest No. of basal branches/plant, stem diameter and straw yield/plant in both seasons were obtained from planting 1500 flax seeds $/ \mathrm{m}^{2}$. On the other hand, sowing flax at plant density of $2500 \mathrm{seeds} / \mathrm{m}^{2}$ markedly recorded the lowest No. of basal branches/plant, stem diameter and straw yield/plant in two seasons. In the first season, flax planting at $1500 \mathrm{seeds} / \mathrm{m}^{2}$ increased straw yield/plant by 13.50 and $29.50 \%$ compared with the growing flax at plant densities of 2000 and 2500 seeds $/ \mathrm{m}^{2}$ respectively, the respective corresponding in the second season were 13.64 and $28.98 \%$. This trend could be explained on the fact that in case of low plant density produced resulted in low competition between plants for nutrient elements, soil moisture and sun light, plants would have better opportunity to produce more metabolite contents and positive effect on plant growth, especially No. of basal branches/plant, stem diameter, straw yield/plant. As well as, such increase in straw yield/plant at flax plant density of 1500 seeds $/ \mathrm{m}^{2}$ could be due to the increases in stem diameter and No. of basal branches/plant of flax. Such results agree with those reported by Omar and Ash-Shormillesy 2006; Ahmed 2010; Abd Eldaiem 2015; El-Borhamy 2016; Fila et al. 2018; Ganvit et al. 2019 and Teshome et al. 2020.

Table 6. Mean values of straw yield and its related traits of flax as affected by plant densities during 2018/2019 $\left(1^{\text {st }}\right)$ and $2019 / 2020\left(2^{\text {nd }}\right)$ seasons.

\begin{tabular}{|c|c|c|c|c|c|c|c|c|c|c|c|c|}
\hline \multirow[t]{2}{*}{$\begin{array}{l}\text { Plant density } \\
\left(\text { seeds } / \mathbf{m}^{2}\right)\end{array}$} & \multicolumn{2}{|c|}{$\begin{array}{c}\text { Total plant } \\
\text { height } \\
(\mathrm{cm})\end{array}$} & \multicolumn{2}{|c|}{$\begin{array}{c}\text { Technical stem } \\
\text { length } \\
(\mathrm{cm})\end{array}$} & \multicolumn{2}{|c|}{$\begin{array}{c}\begin{array}{c}\text { No. of basal } \\
\text { branches } \\
\text { /plant }\end{array} \\
\end{array}$} & \multicolumn{2}{|c|}{$\begin{array}{l}\text { Stem diameter } \\
\qquad(\mathbf{m m})\end{array}$} & \multicolumn{2}{|c|}{$\begin{array}{l}\text { Straw yield/ } \\
\text { plant (g) }\end{array}$} & \multicolumn{2}{|c|}{$\begin{array}{c}\text { Straw yield/fed } \\
(\mathbf{k g})\end{array}$} \\
\hline & $1^{\text {st }}$ & $2^{\text {nd }}$ & $1^{\text {st }}$ & $2^{\text {nd }}$ & $1^{\text {st }}$ & $2^{\text {nd }}$ & $1^{\text {st }}$ & $2^{\text {nd }}$ & $1^{\text {st }}$ & $2^{\text {nd }}$ & $1^{\text {st }}$ & $2^{\text {nd }}$ \\
\hline 1500 & 89.94 & 82.62 & 65.06 & 60.03 & 2.487 & 2.319 & 1.8 & 1.748 & 38 & 2.274 & 370.94 & 3174.86 \\
\hline 2000 & 94.32 & 87.35 & 71.53 & 66.80 & 2.212 & 1.920 & & & 2 . & 01 & 395 & 3768.75 \\
\hline 2500 & 101.92 & 94.84 & 81.87 & 77.00 & 1.614 & 1.514 & 1.548 & 1.371 & 1.844 & 1.763 & 4315.89 & 4116.44 \\
\hline L.S.D. at $5 \%$ & 2.35 & 2.19 & 2.25 & 2.06 & 0.076 & 0.069 & 0.072 & 0.068 & 0.092 & 0.087 & 305.24 & 281.25 \\
\hline
\end{tabular}

4) Effect of interaction between flax cultivars and nitrogen fertilizer rates

All straw yield and its related traits of flax were significantly affected by interaction between flax cultivars and nitrogen fertilizer during both seasons, as shown in Table 7. Sakha 3 cultivar when received $70 \mathrm{~kg} \mathrm{~N} /$ fed produced significantly the maximum total plant height $(107.93$ and $98.20 \mathrm{~cm})$ and technical stem length $(80.64$ and $72.72 \mathrm{~cm})$ in both seasons respectively. While, the lowest total plant height $(86.15$ and $79.98 \mathrm{~cm})$ and technical stem length $(67.22$ and $63.30 \mathrm{~cm})$ in the respective two seasons were obtained from flax planting Giza 11 cultivar with soil fertilized by $30 \mathrm{~kg}$ N/fed. Giza 12 
cultivar under soil fertilized by $70 \mathrm{~kg} \mathrm{~N} /$ fed recorded the highest No. of basal branches/plant (2.810 and 2.633 basal branches), straw yield/plant (2.554 and $2.398 \mathrm{~g}$ ) and straw yield/fed (4653.67 and 4373.42 $\mathrm{kg}$ ) during both seasons respectively. Meanwhile, Sakha 3 cultivar with applied of $30 \mathrm{~kg} \mathrm{~N} /$ fed gave the lowest No. of basal branches/plant (1.463 and 1.290 basal branches), straw yield/plant (1.661 and $1.562 \mathrm{~g})$ and straw yield/fed (3015.50 and $2791.50 \mathrm{~kg}$ ) in both seasons respectively. Giza 11 cultivar when received $70 \mathrm{~kg} \mathrm{~N} /$ fed gave thickness stem diameter by 2.033 and $1.837 \mathrm{~mm}$ in two seasons respectively. On the other hand, thinnest stem diameter (1.263 and 1.183 $\mathrm{mm}$ ) in both seasons respectively was obtained from Sakha 3 cultivar with soil fertilized by $30 \mathrm{~kg} \mathrm{~N} / \mathrm{fed}$. These results agree with those reported by Omar and Ash-Shormillesy 2006; Ahmed 2010; Andruszczak et al. 2015; El-Refaey et al. 2015; El-Borhamy 2016; Ibrahim et al. 2016; Gupta et al. 2017; Abdel-Kader and Mousa 2019 and Emam 2019, found that straw yield and its related traits were significantly affected by interaction between flax cultivars and nitrogen fertilizer rates.

Table 7. Mean values of straw yield and its related traits of flax as affected by interaction between flax cultivars and nitrogen fertilizer rates during 2018/2019 $\left(1^{\text {st }}\right)$ and 2019/2020 $\left(2^{\text {nd }}\right)$ seasons.

\begin{tabular}{|c|c|c|c|c|c|c|c|c|c|c|c|c|c|}
\hline \multirow[t]{2}{*}{$\begin{array}{c}\text { Flax } \\
\text { cultivar }\end{array}$} & \multirow{2}{*}{$\begin{array}{l}\text { Nitrogen } \\
\text { rate } \\
(\mathrm{kg} \mathrm{N} / \mathrm{fed})\end{array}$} & \multicolumn{2}{|c|}{$\begin{array}{c}\begin{array}{c}\text { Total plant } \\
\text { height } \\
(\mathrm{cm})\end{array} \\
\end{array}$} & \multicolumn{2}{|c|}{$\begin{array}{c}\text { Technical } \\
\text { stem length } \\
(\mathrm{cm})\end{array}$} & \multicolumn{2}{|c|}{$\begin{array}{l}\text { No. of basal } \\
\text { branches } \\
\text { /plant }\end{array}$} & \multicolumn{2}{|c|}{$\begin{array}{l}\text { Stem diameter } \\
(\mathbf{m m})\end{array}$} & \multicolumn{2}{|c|}{$\begin{array}{l}\text { Straw yield/ } \\
\text { plant (g) }\end{array}$} & \multicolumn{2}{|c|}{$\begin{array}{c}\text { Straw yield/fed } \\
(\mathrm{kg})\end{array}$} \\
\hline & & $1^{\text {st }}$ & $2^{\text {nd }}$ & $1^{\text {st }}$ & $2^{\text {nd }}$ & $1^{\text {st }}$ & $2^{\text {nd }}$ & $1^{\text {st }}$ & $2^{\text {nd }}$ & $1^{\text {st }}$ & $2^{\text {nd }}$ & $1^{\text {st }}$ & $2^{\text {nd }}$ \\
\hline \multirow{3}{*}{ Sakha 3} & 30 & 98.09 & 90 & 73.21 & 67 & 1.463 & 1.290 & 1.263 & 1.183 & .661 & 1.562 & 015.50 & 2791.50 \\
\hline & 50 & 103.94 & 94.06 & 77.83 & 69.93 & 1.520 & 1.367 & 1.321 & 1.238 & 1.946 & 1.881 & 3612.67 & 3494.83 \\
\hline & 70 & 107.93 & 98.20 & 80.64 & 72.72 & 1.600 & 1.407 & 1.370 & 1.280 & 2.188 & 2.056 & 4116.75 & 3768.92 \\
\hline \multirow{3}{*}{ Giza 11} & 30 & 86.15 & 79.98 & 67.22 & 63.30 & 2.000 & 1.797 & 1.921 & 1.694 & 1.859 & 1.762 & 3418.83 & 3243.67 \\
\hline & 50 & 90.39 & 84.91 & 70.46 & 66.88 & 2.080 & 1.917 & 1.993 & 1.788 & 2.193 & 2.116 & 4034.75 & 3903.83 \\
\hline & 70 & 94.31 & 88.27 & 73.05 & 69.39 & 2.150 & 2.010 & 2.033 & 1.837 & 2.409 & 2.300 & 4428.67 & 4237.58 \\
\hline \multirow{3}{*}{ Giza 12} & 30 & 88.22 & 81.50 & 67.64 & 63.67 & 2.617 & 2.347 & 1.718 & 1.598 & 1.918 & 1.836 & 3486.75 & 3342.00 \\
\hline & 50 & 92.84 & 86.88 & 71.47 & 68.12 & 2.700 & 2.493 & 1.778 & 1.665 & 2.282 & 2.201 & 4161.25 & 4024.42 \\
\hline & 70 & 96.66 & 89.92 & 73.87 & 70.04 & 2.810 & 2.633 & 1.818 & 1.714 & 2.554 & 2.398 & 4653.67 & 4373.42 \\
\hline \multicolumn{2}{|c|}{ L.S.D. at $5 \%$} & 5.18 & 4.99 & 4.94 & 4.57 & 0.154 & 0.132 & 0.140 & 0.130 & 0.168 & 0.161 & 546.06 & 500.03 \\
\hline
\end{tabular}

5) Effect of interaction between flax cultivars and plant densities treatments:

Results in Table 8 indicated that interaction between flax cultivars and plant densities treatments was significant effect on all straw yield and its related traits of flax in both seasons. Sakha 3 cultivar with 2500 seeds $/ \mathrm{m}^{2}$ recorded the maximum total plant height $(111.33$ and $100.75 \mathrm{~cm})$ and technical stem length (86.94 and $78.49 \mathrm{~cm})$ in both seasons respectively. On the other hand, the lowest values of total plant height $(84.77$ and $78.14 \mathrm{~cm})$ and technical stem length $(62.57$ and $58.19 \mathrm{~cm})$ in the respective two seasons were recorded from Giza 11 cultivar at $1500 \mathrm{seeds} / \mathrm{m}^{2}$. The greatest No. of basal branches/plant (3.173 and 3.033 basal branches) and straw yield/plant (2.577 and $2.431 \mathrm{~g}$ ) in both seasons respectively, were obtained from Giza 12 cultivar at 1500 seeds $/ \mathrm{m}^{2}$ as well as, planting the same flax cultivar with 2500 seeds $/ \mathrm{m}^{2}$ significantly recorded the maximum straw yield/fed (4483.92 and $4310.50 \mathrm{~kg}$ ) in two seasons respectively. Meanwhile, Sakha 3 cultivar gave the lowest No. of basal branches/plant (1.113 and 1.047 basal branches) and straw yield/plant (1.765 and $1.662 \mathrm{~g}$ ) under plant density of $2500 \mathrm{seeds} / \mathrm{m}^{2}$ as well as lowest straw yield/fed $(3016.17$ and $2825.58 \mathrm{~kg}$ ) at plant density of 1500 seeds $/ \mathrm{m}^{2}$ in the respective two seasons. The thickness stem diameter (2.117 and $2.002 \mathrm{~mm}$ ) was obtained by Giza 11 cultivar with 1500 seeds $/ \mathrm{m}^{2}$ in both seasons respectively. Whereas, the thinnest stem diameter ( 1.152 and $1.090 \mathrm{~mm}$ in the respective two seasons) was obtained from Sakha 3 cultivar at plant density of 2500 seeds $/ \mathrm{m}^{2}$. The results agree with those reported by Omar and Ash-Shormillesy 2006; Ahmed 2010; Abd El-Mohsen et al. 2013; Abd Eldaiem 2015; Andruszczak et al. 2015; ElBorhamy 2016 and Fila et al. 2018, which reported that there was significantly difference among interaction between flax cultivars and plant densities for straw yield and its related traits.

6) Effect of interaction between nitrogen fertilizer rates and plant densities treatments:

Results in Table 9 showed that interaction effect among nitrogen fertilizer rates and plant densities treatments induced significant differences on all straw yield and its related traits except stem diameter during two seasons. The highest total plant height (106.51 and $98.75 \mathrm{~cm})$, technical stem length $(85.11$ and $80.02 \mathrm{~cm}$ ) and straw yield/fed (4929.58 and $4598.00 \mathrm{~kg}$ ) in two seasons respectively were recorded from growing flax when received $70 \mathrm{~kg}$ $\mathrm{N} /$ fed at plant density of 2500 seeds $/ \mathrm{m}^{2}$. While, sowing flax with the same nitrogen fertilizer rate under plant density 1500 seeds $/ \mathrm{m}^{2}$ gave the maximum No. of basal branches/plant (2.587 and 2.473 basal branches) and straw yield/plant (2.676 and $2.535 \mathrm{~g}$ ) in both seasons respectively. On the 
other hand, flax planting under soil fertilized by 30 $\mathrm{kg} \mathrm{N} /$ fed with 1500 seeds $/ \mathrm{m}^{2}$ gave the lowest total plant height $(84.83$ and $78.14 \mathrm{~cm})$, technical stem length $(60.90$ and $56.52 \mathrm{~cm})$ and straw yield/fed $(2902.58$ and $2749.92 \mathrm{~kg})$ in both seasons respectively, as well as, planting the flax with the same nitrogen fertilizer rate at 2500 seeds $/ \mathrm{m}^{2}$ recorded the lowest No. of basal branches/plant (1.547 and 1.463 basal branches) and straw yield/plant (1.575 and $1.492 \mathrm{~g}$ in two seasons respectively. The results reported here are in harmony with those obtained by Omar and AshShormillesy 2006; Ahmed 2010; Andruszczak et al. 2015 and El-Borhamy 2016.

Table 8. Mean values of straw yield and its related traits of flax as affected by interaction between flax cultivars and plant densities during 2018/2019 $\left(1^{\text {st }}\right)$ and 2019/2020 $\left(2^{\text {nd }}\right)$ seasons.

\begin{tabular}{|c|c|c|c|c|c|c|c|c|c|c|c|c|c|}
\hline \multirow[t]{2}{*}{$\begin{array}{c}\text { Flax } \\
\text { cultivar }\end{array}$} & \multirow{2}{*}{$\begin{array}{c}\text { Plant } \\
\text { density } \\
\left(\operatorname{seeds} / \mathbf{m}^{2}\right)\end{array}$} & \multicolumn{2}{|c|}{$\begin{array}{c}\text { Total plant } \\
\text { height } \\
(\mathbf{c m})\end{array}$} & \multicolumn{2}{|c|}{$\begin{array}{c}\text { Technical } \\
\text { stem length } \\
(\mathrm{cm})\end{array}$} & \multicolumn{2}{|c|}{$\begin{array}{l}\text { No. of basal } \\
\text { branches } \\
\text { /plant } \\
\end{array}$} & \multicolumn{2}{|c|}{$\begin{array}{l}\text { Stem diameter } \\
(\mathbf{m m})\end{array}$} & \multicolumn{2}{|c|}{$\begin{array}{l}\text { Straw yield/ } \\
\text { plant (g) }\end{array}$} & \multicolumn{2}{|c|}{$\begin{array}{c}\text { Straw yield/fed } \\
(\mathbf{k g})\end{array}$} \\
\hline & & $1^{\text {st }}$ & $2^{\text {nd }}$ & 1 st $^{\text {st }}$ & $2^{\text {nd }}$ & $1^{\text {st }}$ & $2^{\text {nd }}$ & $1^{\text {st }}$ & $2^{\text {nd }}$ & 1st $^{\text {st }}$ & $2^{\text {nd }}$ & 1st $^{\text {st }}$ & $2^{\text {nd }}$ \\
\hline \multirow{3}{*}{ Sakha 3} & & 97.13 & 88.82 & 69.15 & 62.64 & 1.833 & 1.630 & 1.469 & .379 & 2.115 & 2.056 & 3016.17 & 2825.58 \\
\hline & 2000 & 101.50 & 93.42 & 75.60 & 68.96 & 1.637 & 1.387 & 1.333 & 31 & 1.915 & 1.781 & 3621.42 & 3390.92 \\
\hline & & 111.33 & 100.75 & 86.94 & 78.49 & 1.113 & 1.047 & & & & 1.662 & $410^{\circ}$ & 8.75 \\
\hline \multirow{3}{*}{ Giza 11} & 1500 & 84.77 & 78.14 & 62.57 & 58.19 & 2.453 & 2.293 & 2.117 & 2.002 & 2.472 & 2.334 & 3488.83 & 3296.08 \\
\hline & 2000 & 89.57 & 83.51 & 69.22 & 65.30 & 2.157 & 1.913 & 1.975 & 1.758 & 2.143 & 2.063 & 4037.00 & 3888.92 \\
\hline & 2500 & 96.51 & 91.50 & 78.95 & 76.08 & 1.620 & 1.517 & 1.854 & 1.559 & 1.847 & 1.780 & 4356.42 & 4200.08 \\
\hline \multirow{3}{*}{ Giza 12} & 1500 & 87.92 & 80.89 & 63.47 & 59.25 & 3.173 & 3.033 & & & & 1 & 360 & 3402.92 \\
\hline & 2000 & 91.89 & 85.13 & 69.78 & 66.15 & 2.843 & 2.460 & 1.777 & 1.652 & 2.255 & 2.157 & 4209.92 & 4026.42 \\
\hline & 2500 & 97.91 & 92.28 & 79.73 & 76.43 & 2.110 & 1.980 & 1.638 & 1.462 & 1.922 & 1.847 & 4483.92 & 4310.50 \\
\hline \multicolumn{2}{|c|}{ L.S.D. at $5 \%$} & 4.07 & 3.79 & 3.90 & 3.57 & 0.132 & 0.120 & 0.125 & 0.118 & 0.159 & 0.151 & 528.69 & 487.14 \\
\hline
\end{tabular}

Table 9. Mean values of straw yield and its related traits of flax as affected by interaction between nitrogen fertilizer rates and plant densities during 2018/2019 $\left(1^{\text {st }}\right)$ and 2019/2020 $\left(2^{\text {nd }}\right)$ seasons.

\begin{tabular}{|c|c|c|c|c|c|c|c|c|c|c|c|c|c|}
\hline \multirow{2}{*}{$\begin{array}{l}\text { Nitrogen } \\
\text { rate } \\
(\mathrm{kg} \mathrm{N} / \mathrm{fed})\end{array}$} & \multirow[t]{2}{*}{$\begin{array}{c}\text { Plant } \\
\text { density } \\
\left(\text { seeds } / \mathbf{m}^{2}\right)\end{array}$} & \multicolumn{2}{|c|}{$\begin{array}{l}\text { Total plant } \\
\text { height } \\
\text { (cm) }\end{array}$} & \multicolumn{2}{|c|}{$\begin{array}{c}\text { Technical } \\
\text { stem length } \\
(\mathrm{cm})\end{array}$} & \multicolumn{2}{|c|}{$\begin{array}{c}\text { No. of basal } \\
\text { branches } \\
\text { /plant }\end{array}$} & \multicolumn{2}{|c|}{$\begin{array}{c}\text { Stem } \\
\text { diameter } \\
(\mathbf{m m})\end{array}$} & \multicolumn{2}{|c|}{$\begin{array}{l}\text { Straw yield/ } \\
\text { plant (g) }\end{array}$} & \multicolumn{2}{|c|}{$\begin{array}{c}\text { Straw yield/fed } \\
(\mathbf{k g})\end{array}$} \\
\hline & & $1^{\text {st }}$ & $2^{\text {nd }}$ & $1^{\text {st }}$ & $2^{\text {nd }}$ & $1^{\text {st }}$ & $2^{\text {nd }}$ & $1^{\text {st }}$ & $2^{\text {nd }}$ & $1^{\text {st }}$ & $2^{\text {nd }}$ & $1^{\text {st }}$ & $2^{\text {nd }}$ \\
\hline \multirow{4}{*}{0} & 1500 & 84.83 & 78.14 & 60.90 & 56.52 & 2.393 & 2.147 & 1.767 & 1.687 & 2.066 & 1.967 & 2902.58 & 2749.92 \\
\hline & 2000 & 90.57 & 83.58 & 68.80 & 64.25 & 2.140 & 1.823 & 1.643 & 1.481 & 1.797 & 1.702 & 3354.67 & 3167.92 \\
\hline & 2500 & 97.05 & 90.49 & 78.37 & 73. & 1.547 & 3 & 91 & 1.307 & 75 & 492 & 63.83 & 9.33 \\
\hline & 1500 & 90.77 & 83.26 & 65.97 & 60.75 & 2.480 & & 1.838 & 1.754 & & 2. & 3422.08 & 3234.42 \\
\hline \multirow[t]{2}{*}{50} & 2000 & 94.22 & 87.30 & 71.67 & 66.85 & 2.200 & 1.923 & 1.702 & 1.556 & 2.137 & 2.042 & 4032.33 & 3896.67 \\
\hline & 2500 & 102.19 & 95.30 & 82.13 & 77.33 & 1.620 & 1.517 & 1.553 & 1.381 & 1.862 & 1.836 & 4354.25 & 4292.00 \\
\hline & 1500 & 94.21 & 86.46 & 68.32 & 62.81 & 2.587 & 2.473 & 1.880 & 1.803 & 2.676 & 2.535 & 3788.17 & 3540.25 \\
\hline \multirow[t]{2}{*}{70} & 2000 & 98.17 & 91.18 & 74.13 & 69.31 & 2.297 & 2.013 & 1.741 & 1.604 & 2.378 & 2.257 & 4481.33 & 4241.67 \\
\hline & 2500 & 106.51 & 98.75 & 85.11 & 80.02 & 1.677 & 1.563 & 1.600 & 1.424 & 2.097 & 1.962 & 4929.58 & 4598.00 \\
\hline \multicolumn{2}{|c|}{ L.S.D. at $5 \%$} & 4.07 & 3.79 & 3.90 & 3.57 & 0.132 & 0.120 & N.S. & N.S. & 0.159 & 0.151 & 528.69 & 487.14 \\
\hline
\end{tabular}

7) Effect of interaction between flax cultivars, nitrogen fertilizer rates and plant densities treatments:

Results in Table $\mathbf{1 0}$ showed significant interaction effect between flax cultivars, nitrogen fertilizer rates and plant densities treatments under study during two experimental seasons on total plant height, technical stem length, straw yield/plant and straw yield/fed of flax. While, No. of basal branches/plant and stem diameter were not significantly affected by interaction in both seasons. The maximum total plant height (116.88 and 105.12 $\mathrm{cm})$ and technical stem length $(91.35$ and $82.02 \mathrm{~cm})$ in both seasons respectively were obtained by Sakha 3 cultivar under soil fertilized by $70 \mathrm{~kg} \mathrm{~N} / \mathrm{fed}$ with plant density of 2500 seeds $/ \mathrm{m}^{2}$. Whereas, Giza 11 cultivar when received $30 \mathrm{~kg} \mathrm{~N} / \mathrm{fed}$ at plant density of 1500 seeds $/ \mathrm{m}^{2}$ gave the lowest total plant height $(80.22$ and $73.58 \mathrm{~cm})$ technical stem length and $(58.57$ and $54.75 \mathrm{~cm})$ in both seasons respectively. The heaviest straw yield/plant (2.916 and $2.712 \mathrm{~g})$ in both seasons respectively which obtained from Giza 12 cultivar with soil fertilized by $70 \mathrm{~kg} \mathrm{~N} /$ fed at plant density of 1500 seeds $/ \mathrm{m}^{2}$. Whereas, Sakha 3 cultivar when received $30 \mathrm{~kg} \mathrm{~N} / \mathrm{fed}$ with plant density of 2500 seeds $/ \mathrm{m}^{2}$ gave the lightest values of straw yield/plant (1.525 and $1.413 \mathrm{~g}$ ) in both seasons respectively. Giza 12 cultivar when received $70 \mathrm{~kg}$ N/fed by plant density of 2500 seeds $/ \mathrm{m}^{2}$ gave the maximum straw yield/fed (5105.50 and $4795.00 \mathrm{~kg}$ in two respective seasons). On the other hand, the minimum values of straw yield/fed (2554.75 and $2416.00 \mathrm{~kg})$ in two 
seasons respectively which obtained from Sakha 3 cultivar when received $30 \mathrm{~kg} \mathrm{~N} /$ fed at plant density of 1500 seeds $/ \mathrm{m}^{2}$. The results agree with those reported by Omar and Ash-Shormillesy 2006; Ahmed 2010; Andruszczak et al. 2015 and El-Borhamy 2016.

Table 10. Mean values of straw yield and its related traits of flax as affected by interaction between flax cultivar, nitrogen fertilizer rates and plant densities during 2018/2019 $\left(1^{\text {st }}\right)$ and 2019/2020 $\left(2^{\text {nd }}\right)$ seasons.

\begin{tabular}{|c|c|c|c|c|c|c|c|c|c|c|c|c|c|c|}
\hline \multirow[t]{2}{*}{$\begin{array}{c}\text { Flax } \\
\text { cultivar }\end{array}$} & \multirow[t]{2}{*}{ rate } & \multirow[t]{2}{*}{$\begin{array}{c}\text { Plant } \\
\text { density }\end{array}$} & \multicolumn{2}{|c|}{$\begin{array}{c}\text { Total plant } \\
\text { height } \\
\text { (cm) }\end{array}$} & \multicolumn{2}{|c|}{$\begin{array}{c}\text { Technical } \\
\text { stem length } \\
(\mathrm{cm})\end{array}$} & \multicolumn{2}{|c|}{$\begin{array}{c}\text { No. of basal } \\
\text { branches } \\
\text { /plant }\end{array}$} & \multicolumn{2}{|c|}{$\begin{array}{c}\text { Stem } \\
\text { diameter } \\
(\mathbf{m m})\end{array}$} & \multicolumn{2}{|c|}{$\begin{array}{c}\text { Straw } \\
\text { yield/plant } \\
\text { (g) }\end{array}$} & \multicolumn{2}{|c|}{$\begin{array}{c}\text { Straw yield/fed } \\
(\mathbf{k g})\end{array}$} \\
\hline & & & 1st $^{\text {st }}$ & $2^{\text {nd }}$ & $1^{\text {st }}$ & $2^{\text {nd }}$ & $1^{\text {st }}$ & $2^{\text {nd }}$ & $1^{\text {st }}$ & $2^{\text {nd }}$ & $1^{\text {st }}$ & $2^{\text {nd }}$ & $1^{\text {st }}$ & $2^{\text {nd }}$ \\
\hline \multirow{10}{*}{$\frac{n}{\pi}$} & \multirow{3}{*}{30} & & 91.86 & & 1 & & 50 & & 413 & & 822 & 753 & 554.75 & 6.00 \\
\hline & & 2000 & 97.03 & 90.51 & 72.32 & 67.11 & 1.560 & 1.330 & 1.291 & 1.163 & 535 & 1.521 & 3013.50 & \\
\hline & & 2500 & 105.37 & 97.06 & 82.21 & 75.59 & 1.080 & 1.020 & 1.084 & 1.053 & .525 & 1.413 & & \\
\hline & \multirow{3}{*}{50} & 1500 & 98.35 & 89.09 & 70.29 & 63.05 & 1.830 & 1.650 & 1.475 & 1.386 & 2.168 & 2.098 & 99.50 & 71.25 \\
\hline & & 2000 & 101.74 & 93.03 & 75.95 & 68.88 & 1.620 & 1.400 & 1.333 & 1.244 & 1.923 & 1.824 & 3680.25 & 3620.50 \\
\hline & & 2500 & 111.74 & 100.07 & 87.25 & 77.86 & 1.110 & 1.050 & 1.156 & 1.083 & 1.746 & 1.721 & 4058.25 & 3992.75 \\
\hline & \multirow{3}{*}{70} & 1500 & 101.18 & 92.75 & 72.05 & 65.25 & 1.920 & 1.720 & 1.518 & 1.418 & 55 & 2.316 & & \\
\hline & & 2000 & 105.73 & 96.73 & 78.52 & 70.88 & 1.730 & 1.430 & 1.376 & 1.286 & 2.186 & 1.999 & & \\
\hline & & 2500 & 116 & & 91.35 & 82 & 1.150 & 1.070 & 1.215 & & 2.023 & 1.853 & & \\
\hline & \multirow{3}{*}{30} & 1500 & 80.22 & 73.58 & 58.57 & 54.75 & 2.360 & 2.110 & 2.052 & 1.935 & 2.153 & 2.033 & 25 & 25 \\
\hline \multirow{8}{*}{ 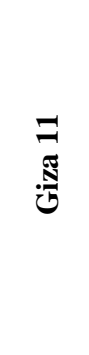 } & & 2000 & 86.12 & 79.25 & 66.88 & 62.56 & 2.110 & 1.830 & 1.913 & 1.692 & 1.846 & 1.752 & .25 & 7.75 \\
\hline & & 2500 & 92.11 & 87.12 & 76.22 & 72.58 & 1.530 & 1.450 & 1.797 & 1.454 & 1.579 & 1.501 & 00 & .00 \\
\hline & \multirow{3}{*}{50} & 1500 & 85.3 & & 63.25 & & 2.450 & & 2.126 & & 506 & 394 & & \\
\hline & & 2000 & 89.23 & 83.59 & 69.02 & 65.02 & 2.150 & 1.920 & 1.986 & 1.765 & 2.191 & 2.091 & 412 & 3940.50 \\
\hline & & 2500 & 96.56 & 92.14 & 79.11 & 76.68 & 1.640 & 1.510 & 1.868 & 1.586 & 1.883 & 1.862 & 44 & 4391.50 \\
\hline & \multirow{3}{*}{70} & 1500 & 88.69 & 81.86 & 65.88 & 60.87 & 2.550 & 2.450 & 2.173 & 2.057 & 2.757 & 2.576 & 388 & 4.50 \\
\hline & & 2000 & 93.36 & 87.69 & 71.75 & 68.33 & 2.210 & 1.990 & 2.027 & 1.816 & 2.391 & 2.347 & 45 & .50 \\
\hline & & 2500 & 100.87 & 95.25 & 81.51 & & 1.690 & 1.5 & 1.898 & 1.638 & 79 & 1.977 & & 4659.75 \\
\hline \multirow{9}{*}{ 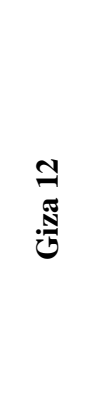 } & \multirow{3}{*}{30} & 1500 & 82.42 & 76.23 & 59.02 & 55.19 & 3.070 & 2.810 & 1.835 & 1.793 & 2.222 & 2.114 & & 2959.50 \\
\hline & & 2000 & 88.57 & 80.99 & 67.21 & 63.07 & 2.750 & 2.310 & 1.725 & 1.587 & 1.911 & 1.833 & 3567.25 & 3421.75 \\
\hline & & 2500 & 93.68 & 87.28 & 76.68 & 72.76 & 2.030 & 1.920 & 1.593 & 1.415 & 1.621 & 1.562 & 3782.25 & 3644.75 \\
\hline & \multirow{3}{*}{50} & 1500 & 88.57 & 81.69 & 64.36 & 60.25 & 3.160 & 3.040 & 1.914 & & 2.593 & 2.466 & & 3452.50 \\
\hline & & 2000 & 91.68 & 85.27 & 70.03 & 66.64 & 2.830 & 2.450 & 1.786 & 1.658 & 2.298 & 2.212 & 4289.50 & 4129.00 \\
\hline & & 2500 & 98.26 & 93.68 & 80.03 & 77.46 & 2.110 & 1.990 & 1.635 & 1.474 & 1.956 & 1.925 & 4564.00 & 4491.75 \\
\hline & \multirow{3}{*}{70} & 1500 & 92.76 & 84.76 & 67.02 & 62.31 & 3.290 & 3.250 & 1.949 & 1.934 & 2.916 & 2.712 & 4082.50 & 3796.75 \\
\hline & & 2000 & 95.43 & 89.12 & 72.11 & 68.73 & 2.950 & 2.620 & 1.819 & 1.710 & 2.557 & 2.426 & 4773.00 & 4528.50 \\
\hline & & 2500 & 101.78 & 95.88 & 82.48 & 79.07 & 2.190 & 2.030 & 1.686 & 1.498 & 2.188 & 2.055 & 5105.50 & 4795.00 \\
\hline \multicolumn{3}{|c|}{ L.S.D. at $5 \%$} & 7.05 & 6.57 & 6.75 & 6.18 & N.S. & N.S. & N.S. & N.S. & 0.276 & 0.261 & 915.72 & 843.75 \\
\hline
\end{tabular}

\section{B- Fiber yield and its related traits:}

\section{1) Effect of flax cultivars:}

All fiber yield and its related traits were significantly affected by three tested flax cultivars under study, but the differences in total fiber percentage, fiber yield/plant and fiber yield/fed between Giza 11 and Giza 12 were not significant in both seasons, as shown in Table 11. Sakha 3 cultivar significantly produced the maximum total fiber percentage, fiber yield/plant, fiber yield/fed, fiber length and fiber fineness in both seasons. On the other hand, the lowest total fiber percentage, fiber yield/plant, fiber yield/fed, fiber length and fiber fineness were obtained from Giza 11 cultivar in both seasons. The superiority ratios in the first season between flax cultivar of Sakha 3 and each of Giza 12 and Giza 11 were 42.12 and $46.74 \%$ for total fiber percentage; 22.13 and $32.12 \%$ for fiber yield/plant; 24.35 and $32.82 \%$ for fiber yield/fed; 4.07 and 7.89 $\%$ for fiber length in addition to 37.68 and $45.09 \%$ for fiber fineness, respectively. The excess ratios in the second season when flax planting Sakha 3 cultivar over each of Giza 12 and Giza 11 cultivars were 43.58 and $49.66 \%$ for total fiber percentage; 22.89 and $33.77 \%$ for fiber yield/plant; 23.21 and $32.14 \%$ for fiber yield/fed; 3.61 and $9.90 \%$ for fiber length in addition to 39.17 and $46.89 \%$ for fiber fineness, respectively. The differences among flax cultivars were mainly due to the differences in the genetical constituents between flax cultivar of Sakha 3 (fiber flax type) and flax cultivars of Giza 11 and Giza 12 (dual purpose type). As well as, the increase in fiber yield/fed of Sakha 3 cultivar may be due to the increases in total fiber percentage and fiber yield/plant. Also, the increase in fiber fineness with 
flax cultivar of Sakha 3 resulted from the decreases in fiber thickness. These results are reported by Omar and Ash-Shormillesy 2006; Ahmed 2010; Abd ElMohsen et al. 2013; Abd Eldaiem 2015; El-Refaey et al. 2015; El-Borhamy 2016; Ibrahim et al. 2016; Fila et al. 2018 and Abdel-Kader and Mousa 2019, indicated great variations in fiber yield and its related traits with flax cultivars.

Table 11. Mean values of fiber yield and its related traits of flax cultivars during 2018/2019 (1 $\left.{ }^{\text {st }}\right)$ and 2019/2020 $\left(2^{\text {nd }}\right)$ seasons.

\begin{tabular}{ccccccccccc}
\hline \multirow{2}{*}{ Flax cultivar } & \multicolumn{2}{c}{$\begin{array}{c}\text { Total fiber } \\
(\boldsymbol{\%})\end{array}$} & \multicolumn{2}{c}{$\begin{array}{c}\text { Fiber yield/plant } \\
(\mathbf{g})\end{array}$} & \multicolumn{2}{c}{$\begin{array}{c}\text { Fiber yield/fed } \\
(\mathbf{k g})\end{array}$} & \multicolumn{2}{c}{$\begin{array}{c}\text { Fiber length } \\
(\mathbf{c m})\end{array}$} & \multicolumn{2}{c}{$\begin{array}{c}\text { Total fiber } \\
(\boldsymbol{\%})\end{array}$} \\
\cline { 2 - 12 } & $\mathbf{1}^{\text {st }}$ & $\mathbf{2}^{\text {nd }}$ & $\mathbf{1}^{\text {st }}$ & $\mathbf{2}^{\text {nd }}$ & $\mathbf{1}^{\text {st }}$ & $\mathbf{2}^{\text {nd }}$ & $\mathbf{1}^{\text {st }}$ & $\mathbf{2}^{\text {nd }}$ & $\mathbf{1}^{\text {st }}$ & $\mathbf{2}^{\text {nd }}$ \\
\hline Sakha 3 & 22.54 & 22.24 & 0.436 & 0.408 & 815.21 & 753.56 & 70.52 & 67.48 & 202.41 & 210.84 \\
Giza 11 & 15.36 & 14.86 & 0.330 & 0.305 & 613.79 & 570.28 & 65.36 & 61.40 & 139.51 & 143.54 \\
Giza 12 & 15.86 & 15.49 & 0.357 & 0.332 & 655.59 & 611.63 & 67.76 & 65.13 & 147.01 & 151.50 \\
\hline L.S.D. at 5 \% & $\mathbf{1 . 1 6}$ & $\mathbf{1 . 0 7}$ & $\mathbf{0 . 0 3 7}$ & $\mathbf{0 . 0 3 1}$ & $\mathbf{6 3 . 2 5}$ & $\mathbf{5 9 . 8 7}$ & $\mathbf{1 . 5 1}$ & $\mathbf{1 . 3 8}$ & $\mathbf{6 . 2 3}$ & $\mathbf{5 . 1 1}$ \\
\hline
\end{tabular}

\section{2) Effect of nitrogen fertilizer rates:}

Results in Table 12 showed that increasing nitrogen fertilizer rates from 30 and 50 to $70 \mathrm{~kg}$ $\mathrm{N} /$ fed caused significant increases in total fiber percentage, fiber yield/plant, fiber yield/fed and fiber length of flax in both seasons. On the other hand, fiber fineness which significantly decreased with increasing nitrogen rates, but the differences in total fiber percentage between 30 and $50 \mathrm{~kg} \mathrm{~N} /$ fed as well as among 50 and $70 \mathrm{~kg} \mathrm{~N} /$ fed not reach the level of significance in both seasons. The maximum total fiber percentage, fiber yield/plant, fiber yield/fed and fiber length in both seasons were obtained when flax planting under soil fertilizer by $70 \mathrm{~kg} \mathrm{~N} / \mathrm{fed}$. Whereas, flax planting with $30 \mathrm{~kg} \mathrm{~N} /$ fed significantly gave the minimum total fiber percentage, fiber yield/plant, fiber yield/fed and fiber length in two seasons. The superiority ratios in the first season between the highest nitrogen rate $(70 \mathrm{~kg} \mathrm{~N} / \mathrm{fed})$ and each of 50 and $30 \mathrm{~kg} \mathrm{~N} /$ fed were 3.72 and $9.43 \%$ for total fiber percentage; 15.83 and $44.41 \%$ for fiber yield/plant; 16.28 and $46.21 \%$ for fiber yield/fed in addition to 3.30 and $9.56 \%$ for fiber length, respectively. The increase ratios in the second season when flax received $70 \mathrm{~kg} \mathrm{~N} /$ fed over each of 50 and $30 \mathrm{~kg} \mathrm{~N} /$ fed were 4.27 and $9.89 \%$ for total fiber percentage; 13.73 and $43.97 \%$ for fiber yield/plant; 12.82 and $45.64 \%$ for fiber yield/fed in addition to 3.35 and $8.93 \%$ for fiber length, respectively. The increase in the fiber length with increasing nitrogen fertilizer levels might be due to increase in technical stem length. In addition to, the increase in fiber yield/fed of flax due to the increase in nitrogen rates is attributed to the increases in total plant height, technical stem length, stem diameter, straw yield/plant, straw yield/fed, total fiber percentage and fiber yield/plant. These results are in harmony with those obtained by Omar and Ash-Shormillesy 2006; Ahmed 2010; El-Refaey et al. 2015; ElBorhamy 2016; Ibrahim et al. 2016; El-Shimy et al. 2017; Gupta et al. 2017; El-Gedwy et al. 2018 and Abdel-Kader and Mousa 2019. The softness fiber fineness was recorded from flax planting when received $30 \mathrm{~kg} \mathrm{~N} /$ fed being 169.72 and $174.81 \mathrm{Nm}$ in both seasons respectively. On the other hand, the coarser fiber with fiber fineness was obtained from flax planting with $70 \mathrm{~kg} \mathrm{~N} /$ fed by 156.42 and 162.50 $\mathrm{Nm}$ in both season, respectively. The applying of 50 and $70 \mathrm{~kg} \mathrm{~N} / \mathrm{fed}$ induced a significant decreases in fiber fineness over $30 \mathrm{~kg} \mathrm{~N} / \mathrm{fed}$ by 4.08 and $7.84 \%$, in the first season and by 3.56 and $7.04 \%$, in the second season, respectively. The decrease in fiber fineness with increasing in nitrogen fertilizer rates may be attributed to increase in fiber thickness. The finding is agreement with those obtained by ElNagdy et al. 2010; El-Refaey et al. 2015; El-Shimy et al. 2017 and El-Gedwy et al. 2018.

Table 12. Mean values of fiber yield and its related traits of flax as affected by nitrogen fertilizer rates during $2018 / 2019\left(1^{\text {st }}\right)$ and $2019 / 2020\left(2^{\text {nd }}\right)$ seasons.

\begin{tabular}{ccccccccccc}
\hline \multirow{2}{*}{$\begin{array}{c}\text { Nitrogen rate } \\
(\mathbf{k g ~ N} / \mathbf{f e d})\end{array}$} & \multicolumn{2}{c}{$\begin{array}{c}\text { Total fiber } \\
(\boldsymbol{\%})\end{array}$} & \multicolumn{2}{c}{$\begin{array}{c}\text { Fiber yield/plant } \\
(\mathbf{g})\end{array}$} & \multicolumn{2}{c}{$\begin{array}{c}\text { Fiber yield/fed } \\
(\mathbf{k g})\end{array}$} & \multicolumn{2}{c}{$\begin{array}{c}\text { Fiber length } \\
(\mathbf{c m})\end{array}$} & \multicolumn{2}{c}{$\begin{array}{c}\text { Total fiber } \\
(\boldsymbol{\%})\end{array}$} \\
\cline { 2 - 12 } & $\mathbf{1}^{\text {st }}$ & $\mathbf{2}^{\text {nd }}$ & $\mathbf{1}^{\text {st }}$ & $\mathbf{2}^{\text {nd }}$ & $\mathbf{1}^{\text {st }}$ & $\mathbf{2}^{\text {nd }}$ & $\mathbf{1}^{\text {st }}$ & $\mathbf{2}^{\text {nd }}$ & $\mathbf{1}^{\text {st }}$ & $\mathbf{2}^{\text {nd }}$ \\
\hline $\mathbf{3 0}$ & 17.07 & 16.68 & 0.304 & 0.282 & 560.45 & 516.51 & 64.52 & 61.72 & 169.72 & 174.81 \\
$\mathbf{5 0}$ & 18.01 & 17.58 & 0.379 & 0.357 & 704.71 & 666.75 & 68.43 & 65.05 & 162.79 & 168.58 \\
$\mathbf{7 0}$ & 18.68 & 18.33 & 0.439 & 0.406 & 819.42 & 752.22 & 70.69 & 67.23 & 156.42 & 162.50 \\
\hline L.S.D. at 5 \% & $\mathbf{1 . 0 3}$ & $\mathbf{0 . 9 9}$ & $\mathbf{0 . 0 2 6}$ & $\mathbf{0 . 0 2 4}$ & $\mathbf{5 6 . 5 7}$ & $\mathbf{5 2 . 1 8}$ & $\mathbf{1 . 1 7}$ & $\mathbf{0 . 9 8}$ & $\mathbf{4 . 1 9}$ & $\mathbf{4 . 0 2}$ \\
\hline
\end{tabular}

\section{3) Effect of plant densities treatments:}

Results in Table 13 show that increasing plant density from 1500 to 2500 seeds $/ \mathrm{m}^{2}$ caused significantly increment in total fiber percentage, fiber yield/fed, fiber length and fiber fineness during both seasons. On the other hand, fiber yield/plant was significantly decreased by increasing plant density from 1500 to 2500 seeds $/ \mathrm{m}^{2}$ in both seasons. Flax 
sowing at $2500 \mathrm{seeds} / \mathrm{m}^{2}$ significantly produced the maximum total fiber percentage, fiber yield/fed, fiber length and fiber fineness as well as gave the lightest fiber yield/plant $(0.346$ and $0.327 \mathrm{~g})$ in both seasons. On the other hand, flax planting at $1500 \mathrm{seeds} / \mathrm{m}^{2}$ gave the lowest total fiber percentage, fiber yield/fed, fiber length and fiber fineness as well as gave the heaviest fiber yield/plant in both seasons. The superiority ratios in the first season between sowing flax at plant density of 2500 seeds $/ \mathrm{m}^{2}$ and each of 2000 and 1500 seeds $/ \mathrm{m}^{2}$ were 3.24 and $11.85 \%$ for total fiber percentage; 13.22 and $44.30 \%$ for fiber yield/fed; 15.23 and $27.17 \%$ for fiber length in addition to 7.43 and $19.24 \%$ for fiber fineness, respectively. The increase ratios in the second season when flax growing at 2500 seeds $/ \mathrm{m}^{2}$ over each of 2000 and 1500 seeds $/ \mathrm{m}^{2}$ were 4.79 and $14.06 \%$ for total fiber percentage; 15.04 and $48.84 \%$ for fiber yield/fed; 15.06 and $28.02 \%$ for fiber length in addition to 5.28 and $16.85 \%$ for fiber fineness, respectively. Flax sowing at plant density of 2500 seeds $/ \mathrm{m}^{2}$ in $2018 / 2019$ season caused significantly decreased in fiber yield/plant by 8.95 and $12.85 \%$ compared with the flax growing at plant density of 2000 and 1500 seeds $/ \mathrm{m}^{2}$, respectively. In the second season, the corresponding decreases in fiber yield/plant were 6.84 and $10.90 \%$. The decreases in fiber yield/plant with increasing plant densities from 1500 to 2500 seeds $/ \mathrm{m}^{2}$ could be due to the decreases in straw yield/plant. Such increases in fiber yield/fed at $2500 \mathrm{seeds} / \mathrm{m}^{2}$ could be due to the increase in No. of flax plants $/ \mathrm{m}^{2}$, straw yield/fed and total fiber percentage of flax. It was clear that the increases in fiber length with plant density of $2500 \mathrm{seeds} / \mathrm{m}^{2}$ may be due to the increases in total plant height and technical stem length. The increase in fiber fineness with increasing in plant densities treatments may be attributed to decrease in fiber thickness. The finding is agreement with those obtained by Omar and AshShormillesy 2006; Ahmed 2010; Abd El-Mohsen et al. 2013; Abd Eldaiem 2015; El-Borhamy 2016 and Fila et al. 2018.

Table 13. Mean values of fiber yield and its related traits of flax as affected by plant densities during 2018/2019 $\left(1^{\text {st }}\right)$ and $2019 / 2020\left(2^{\text {nd }}\right)$ seasons.

\begin{tabular}{cccccccccccc}
\hline \multirow{2}{*}{$\begin{array}{c}\text { Plant density } \\
\left(\mathbf{s e e d s} / \mathbf{m}^{2}\right)\end{array}$} & \multicolumn{2}{c}{$\begin{array}{c}\text { Total fiber } \\
(\boldsymbol{\%})\end{array}$} & \multicolumn{2}{c}{$\begin{array}{c}\text { Fiber yield/plant } \\
(\mathbf{g})\end{array}$} & \multicolumn{2}{c}{$\begin{array}{c}\text { Fiber yield/fed } \\
(\mathbf{k g})\end{array}$} & \multicolumn{2}{c}{$\begin{array}{c}\text { Fiber length } \\
(\mathbf{c m})\end{array}$} & \multicolumn{2}{c}{$\begin{array}{c}\text { Total fiber } \\
(\boldsymbol{\%})\end{array}$} \\
\cline { 2 - 12 } & $\mathbf{1}^{\text {st }}$ & $\mathbf{2}^{\text {nd }}$ & $\mathbf{1}^{\text {st }}$ & $\mathbf{2}^{\text {nd }}$ & $\mathbf{1}^{\text {st }}$ & $\mathbf{2}^{\text {nd }}$ & $\mathbf{1}^{\text {st }}$ & $\mathbf{2}^{\text {nd }}$ & $\mathbf{1}^{\text {st }}$ & $\mathbf{2}^{\text {nd }}$ \\
\hline $\mathbf{1 5 0 0}$ & 16.79 & 16.29 & 0.397 & 0.367 & 560.75 & 511.73 & 60.33 & 57.18 & 148.06 & 154.31 \\
$\mathbf{2 0 0 0}$ & 18.19 & 17.73 & 0.380 & 0.351 & 714.68 & 662.10 & 66.58 & 63.62 & 164.33 & 171.27 \\
$\mathbf{2 5 0 0}$ & 18.78 & 18.58 & 0.346 & 0.327 & 809.16 & 761.65 & 76.72 & 73.20 & 176.54 & 180.31 \\
\hline L.S.D. at 5 \% & $\mathbf{0 . 9 5}$ & $\mathbf{0 . 9 3}$ & $\mathbf{0 . 0 2 1}$ & $\mathbf{0 . 0 1 8}$ & $\mathbf{5 4 . 1 9}$ & $\mathbf{4 8 . 7 3}$ & $\mathbf{1 . 1 4}$ & $\mathbf{0 . 9 3}$ & $\mathbf{4 . 1 1}$ & $\mathbf{3 . 8 7}$ \\
\hline
\end{tabular}

4) Effect of interaction between flax cultivars and nitrogen fertilizer rates:

Interaction effect between flax cultivars and nitrogen fertilizer rates was significant on total fiber percentage, fiber yield/plant, fiber yield/fed, fiber length and fiber fineness of flax in two growing seasons, as shown in Table 14. Sakha 3 cultivar with received $70 \mathrm{~kg} \mathrm{~N} / \mathrm{fed}$ recorded the highest total fiber percentage (23.34 and $23.13 \%)$, fiber yield/plant $(0.509$ and $0.474 \mathrm{~g})$, fiber yield/fed (966.20 and $876.04 \mathrm{~kg})$ and fiber length $(73.76$ and $70.03 \mathrm{~cm})$ in both seasons respectively. While, the lowest total fiber percentage (14.64 and $14.05 \%)$, fiber yield/plant $(0.270$ and $0.246 \mathrm{~g})$, fiber yield/fed $(502.62$ and $457.83 \mathrm{~kg})$ and fiber length (62.28 and $58.23 \mathrm{~cm})$ were obtained from Giza 11 cultivar with soil fertilized by $30 \mathrm{~kg} \mathrm{~N} / \mathrm{fed}$ in the respective two seasons. Sakha 3 cultivar when received $30 \mathrm{~kg} \mathrm{~N} / \mathrm{fed}$ significantly produced the softness fiber fineness (211.67 and $218.63 \mathrm{Nm}$ ) in two seasons respectively. Whereas, Giza 11 cultivar and soil fertilized by $70 \mathrm{~kg}$ $\mathrm{N} /$ fed gave the coarser fiber with fiber fineness 134.43 and $138.97 \mathrm{Nm}$ in both seasons respectively. These results are in agreement with that obtained by Omar and Ash-Shormillesy 2006; Ahmed 2010; El-Refaey et al. 2015; El-Borhamy 2016; Ibrahim et al. 2016; Gupta et al. 2017 and Abdel-Kader and Mousa 2019, found that fiber yield and its related traits were significantly affected by interaction between flax cultivars and nitrogen fertilizer rates.

\section{5) Effect of interaction between flax cultivars and plant densities treatments:}

As shown in Table $\mathbf{1 5}$ interaction between flax cultivars and plant densities on total fiber percentage, fiber yield/plant, fiber yield/fed, fiber length and fiber fineness were significant during both seasons. The greatest total fiber percentage (23.52 and $23.44 \%$ ), fiber yield/fed (970.51 and $903.83 \mathrm{~kg}$ ), fiber length $(79.74$ and $75.52 \mathrm{~cm})$ and fiber fineness (226.57 and $231.83 \mathrm{Nm}$ ) in both seasons respectively were obtained from Sakha 3 cultivar at plant density of 2500 seeds $/ \mathrm{m}^{2}$ also, the same flax cultivar with 1500 seeds $/ \mathrm{m}^{2}$ recorded the maximum fiber yield/plant $(0.449$ and $0.428 \mathrm{~g})$ in both seasons respectively. Meanwhile, Giza 11 cultivar with $1500 \mathrm{seeds} / \mathrm{m}^{2}$ gave the lowest total fiber percentage (14.23 and $13.66 \%$ ), fiber yield/fed (498.30 and $451.65 \mathrm{~kg}$ ), fiber length $(57.86$ and $53.38 \mathrm{~cm})$ and fiber fineness (129.70 and $134.37 \mathrm{Nm}$ ) in both seasons respectively, as well as, the same flax cultivar with $2500 \mathrm{seeds} / \mathrm{m}^{2}$ recorded the lowest fiber yield/plant (0.301 and 0.285 g) in both seasons respectively. These results in good accordance with those reported by Omar and AshShormillesy 2006; Ahmed 2010; Abd El-Mohsen et 
al. 2013; Abd Eldaiem 2015; El-Borhamy 2016 and Fila et al. 2018, found that fiber yield and its related traits were significantly affected by flax cultivars and plant densities interaction.

Table 14. Mean values of fiber yield and its related traits of flax as affected by interaction between flax cultivars and nitrogen fertilizer rates during 2018/2019 $\left(1^{\text {st }}\right)$ and 2019/2020 $\left(2^{\text {nd }}\right)$ seasons.

\begin{tabular}{|c|c|c|c|c|c|c|c|c|c|c|c|}
\hline \multirow{2}{*}{$\begin{array}{c}\text { Flax } \\
\text { cultivar }\end{array}$} & \multirow{2}{*}{$\begin{array}{c}\text { Nitrogen } \\
\text { rate } \\
(\mathrm{kg} \mathrm{N} / \mathrm{fed})\end{array}$} & \multicolumn{2}{|c|}{$\begin{array}{c}\text { Total fiber } \\
(\%)\end{array}$} & \multicolumn{2}{|c|}{$\begin{array}{c}\text { Fiber yield/plant } \\
\text { (g) }\end{array}$} & \multicolumn{2}{|c|}{$\begin{array}{c}\text { Fiber yield/fed } \\
\text { (kg) }\end{array}$} & \multicolumn{2}{|c|}{$\begin{array}{l}\text { Fiber length } \\
(\mathrm{cm})\end{array}$} & \multicolumn{2}{|c|}{$\begin{array}{l}\text { Fiber fineness } \\
(\mathrm{Nm})\end{array}$} \\
\hline & & $1^{\text {st }}$ & $2^{\text {nd }}$ & $1^{\text {st }}$ & $2^{\text {nd }}$ & $1^{\text {st }}$ & $2^{\text {nd }}$ & $1^{\text {st }}$ & $2^{\text {nd }}$ & $1^{\text {st }}$ & $2^{\text {nd }}$ \\
\hline \multirow{3}{*}{ Sakha 3} & 30 & 21.49 & 21.19 & 0.356 & 0.329 & 651.19 & 594.96 & 66.70 & 65.02 & 211.67 & 218.63 \\
\hline & 50 & 22.80 & 22.41 & 0.442 & 0.419 & 828.23 & 789.67 & 71.09 & 67.39 & 202.20 & 210.27 \\
\hline & 70 & 23.34 & 23.13 & 0.509 & 0.474 & 966.20 & 876.04 & 73.76 & 70.03 & 193.37 & 203.63 \\
\hline \multirow{3}{*}{ Giza 11} & 30 & 14.64 & 14.05 & 0.270 & 0.246 & 502.62 & 457.83 & 62.28 & 58.23 & 144.87 & 148.90 \\
\hline & 50 & 15.38 & 14.90 & 0.335 & 0.313 & 623.74 & 585.60 & 65.67 & 61.96 & 139.23 & 142.77 \\
\hline & 70 & 16.06 & 15.64 & 0.385 & 0.357 & 715.02 & 667.42 & 68.13 & 64.02 & 134.43 & 138.97 \\
\hline \multirow{3}{*}{ Giza 12} & 30 & 15.07 & 14.81 & 0.287 & 0.271 & 527.55 & 496.73 & 64.57 & 61.92 & 152.63 & 156.90 \\
\hline & 50 & 15.85 & 15.44 & 0.360 & 0.338 & 662.17 & 624.98 & 68.53 & 65.82 & 146.93 & 152.70 \\
\hline & 70 & 16.64 & 16.23 & 0.423 & 0.387 & 777.04 & 713.19 & 70.18 & 67.64 & 141.47 & 144.90 \\
\hline \multicolumn{2}{|c|}{ L.S.D. at $5 \%$} & 1.78 & 1.71 & 0.045 & 0.042 & 97.98 & 90.38 & 2.03 & 1.70 & 7.26 & 9.96 \\
\hline
\end{tabular}

Table 15. Mean values of fiber yield and its related traits of flax as affected by interaction between flax cultivars and plant densities during 2018/2019 $\left(1^{\text {st }}\right)$ and 2019/2020 $\left(2^{\text {nd }}\right)$ seasons.

\begin{tabular}{|c|c|c|c|c|c|c|c|c|c|c|c|}
\hline \multirow{2}{*}{$\begin{array}{c}\text { Flax } \\
\text { cultivar }\end{array}$} & \multirow{2}{*}{$\begin{array}{c}\text { Plant } \\
\text { density } \\
\left(\text { seeds } / \mathbf{m}^{2}\right)\end{array}$} & \multicolumn{2}{|c|}{$\begin{array}{c}\text { Total fiber } \\
(\%)\end{array}$} & \multicolumn{2}{|c|}{$\begin{array}{c}\text { Fiber yield/plant } \\
\text { (g) }\end{array}$} & \multicolumn{2}{|c|}{$\begin{array}{c}\text { Fiber yield/fed } \\
(\mathbf{k g})\end{array}$} & \multicolumn{2}{|c|}{$\begin{array}{l}\text { Fiber length } \\
(\mathrm{cm})\end{array}$} & \multicolumn{2}{|c|}{$\begin{array}{l}\text { Fiber fineness } \\
(\mathrm{Nm})\end{array}$} \\
\hline & & $\mathbf{1}^{\text {st }}$ & $2^{\text {nd }}$ & $\mathbf{1}^{\text {st }}$ & $2^{\text {nd }}$ & $\mathbf{1}^{\text {st }}$ & $2^{\text {nd }}$ & $\mathbf{1}^{\text {st }}$ & $2^{\text {nd }}$ & $1^{\text {st }}$ & $2^{\text {nd }}$ \\
\hline \multirow{3}{*}{ Sakha 3} & 1500 & 21.14 & 20.70 & 0.449 & 0.428 & 640.09 & 587.96 & 62.84 & 60.46 & 177.83 & 185.53 \\
\hline & 2000 & 22.97 & 22.60 & 0.441 & 0.404 & 835.02 & 768.87 & 68.96 & 66.46 & 202.83 & 215.17 \\
\hline & 2500 & 23.52 & 23.44 & 0.417 & 0.391 & 970.51 & 903.84 & 79.74 & 75.52 & 226.57 & 231.83 \\
\hline \multirow{3}{*}{ Giza 11} & 1500 & 14.23 & 13. & 0.353 & 0.320 & 498.30 & 451.65 & 57.86 & 53.38 & 129.70 & 134.37 \\
\hline & 2000 & 15.62 & 15.00 & 0.336 & 0.311 & 633.14 & 587.00 & 63.86 & 60.45 & 141.23 & 144.87 \\
\hline & 2500 & 16.23 & 15.93 & 0.301 & 0.285 & 709.93 & 672.20 & 74.36 & 70.38 & 147.60 & 151.40 \\
\hline \multirow{3}{*}{ Giza 12} & 1500 & 14.99 & 14.52 & 0.388 & 0.354 & 543.85 & 495.58 & 60.29 & 57.71 & 136.63 & 143.03 \\
\hline & 2000 & 15.98 & 15.59 & 0.362 & 0.338 & 675.86 & 630.43 & 66.93 & 63.95 & 148.93 & 153.77 \\
\hline & 2500 & 16.59 & 16.37 & 0.320 & 0.304 & 747.04 & 708.89 & 76.06 & 73.72 & 155.47 & 157.70 \\
\hline \multicolumn{2}{|c|}{ L.S.D. at $5 \%$} & 1.65 & 1.61 & 0.036 & 0.031 & 93.86 & 84.40 & 1.97 & 1.61 & 7.12 & 6.70 \\
\hline
\end{tabular}

6) Effect of interaction between nitrogen fertilizer rate and plant densities treatments:

Results recorded in Table $\mathbf{1 6}$ indicate that interaction between nitrogen fertilizer rates and plant densities treatments in both seasons has significant effect on fiber yield/plant, fiber yield/fed, fiber length and fiber fineness of flax, while, total fiber percentage was not significantly affected by interaction between flax cultivars and plant densities treatments in both seasons. Flax planting with soil fertilized by $70 \mathrm{~kg} \mathrm{~N} / \mathrm{fed}$ at 2500 seeds $/ \mathrm{m}^{2}$ gave the highest fiber yield/fed (960.57 and $886.00 \mathrm{~kg}$ ) and longest fiber length $(79.91$ and $75.86 \mathrm{~cm})$ in both seasons respectively. On the other hand, the lowest fiber yield/fed (456.16 and $421.50 \mathrm{~kg}$ ) and shortest fiber length $(56.59$ and $53.85 \mathrm{~cm}$ ) in two respective seasons were obtained from applying $30 \mathrm{~kg} \mathrm{~N} /$ fed at 1500 seeds $/ \mathrm{m}^{2}$. Flax planting when received $70 \mathrm{~kg}$ $\mathrm{N} / \mathrm{fed}$ at 1500 seeds $/ \mathrm{m}^{2}$ gave the heaviest fiber yield/plant (0.464 and $0.429 \mathrm{~g})$ as well as gave the coarser fiber with fiber fineness (140.83 and 147.87 $\mathrm{Nm}$ in the respective two seasons). On the other hand, the lightest fiber yield/plant $(0.280$ and 0.261 g) as well as the softness fiber fineness (182.77 and $185.83 \mathrm{Nm}$ ) in both seasons respectively were obtained from applying $30 \mathrm{~kg} \mathrm{~N} /$ fed at plant density of 2500 seeds $/ \mathrm{m}^{2}$. Similar results were reported by Omar and Ash-Shormillesy 2006; Ahmed 2010 and El-Borhamy 2016.

7) Effect of interaction between flax cultivars, nitrogen fertilizer rate and plant densities treatments:

Results in Table 17 revealed that interaction between flax cultivars $\mathrm{X}$ nitrogen fertilizer rates $\mathrm{X}$ plant densities treatments had significant effect on fiber yield/plant, fiber yield/fed, fiber length and fiber fineness of flax, while, total fiber percentage was not significantly affected by interaction in both seasons. The maximum fiber yield/plant $(0.518$ and $0.509 \mathrm{~g}$ in two respective seasons) was obtained from Sakha 3 cultivar when soil fertilized by $70 \mathrm{~kg} \mathrm{~N} /$ fed and using plant density of 1500 seeds $/ \mathrm{m}^{2}$. On the other hand, the minimum fiber yield/plant $(0.244$ and $0.227 \mathrm{~g})$ in both seasons respectively was produced from Giza 11 cultivar when received $30 \mathrm{~kg} \mathrm{~N} / \mathrm{fed}$ at plant density of 
2500 seeds $/ \mathrm{m}^{2}$. The heaviest fiber yield/fed (1164.79 and $1051.40 \mathrm{~kg}$ ) and the longest fiber length (83.93 and $78.87 \mathrm{~cm}$ ) in both seasons respectively were obtained by Sakha 3 cultivar with $70 \mathrm{~kg} \mathrm{~N} /$ fed at plant density of 2500 seeds $/ \mathrm{m}^{2}$. Whereas, Giza 11 cultivar when received $30 \mathrm{~kg} \mathrm{~N} / \mathrm{fed}$ at plant density of $1500 \mathrm{seeds} / \mathrm{m}^{2}$ gave the lowest fiber yield/fed (413.14 and $376.81 \mathrm{~kg}$ ) and the shortest fiber length $(54.69$ and $50.11 \mathrm{~cm}$ ) in both seasons respectively. The most effective interaction treatment for produced the softness fiber fineness was Sakha 3 cultivar with 30 $\mathrm{kg} \mathrm{N} / \mathrm{fed}$ at plant density of 2500 seeds $/ \mathrm{m}^{2}$ (233.60 and $239.70 \mathrm{Nm}$ ) during both seasons respectively. Meanwhile, Giza 11 cultivar under soil fertilized by $70 \mathrm{~kg} \mathrm{~N} / \mathrm{fed}$ with plant density of $1500 \mathrm{seeds} / \mathrm{m}^{2}$ recorded the coarser fiber with fiber fineness 123.80 and $129.70 \mathrm{Nm}$ during both seasons respectively. These results agree with those obtained by Omar and Ash-Shormillesy 2006; Ahmed 2010 and ElBorhamy 2016.

Table 16. Mean values of fiber yield and its related traits of flax as affected by interaction between nitrogen fertilizer rates and plant densities during 2018/2019 $\left(1^{\text {st }}\right)$ and 2019/2020 $\left(2^{\text {nd }}\right)$ seasons.

\begin{tabular}{|c|c|c|c|c|c|c|c|c|c|c|c|}
\hline \multirow{2}{*}{$\begin{array}{l}\text { Nitrogen } \\
\text { rate } \\
(\mathrm{kg} \mathrm{N} / \mathrm{fed})\end{array}$} & \multirow{2}{*}{$\begin{array}{c}\text { Plant } \\
\text { density } \\
\left(\text { seeds } / \mathbf{m}^{2}\right)\end{array}$} & \multicolumn{2}{|c|}{$\begin{array}{c}\text { Total fiber } \\
(\%)\end{array}$} & \multicolumn{2}{|c|}{$\begin{array}{c}\text { Fiber yield/plant } \\
\text { (g) }\end{array}$} & \multicolumn{2}{|c|}{$\begin{array}{c}\text { Fiber yield/fed } \\
(\mathrm{kg})\end{array}$} & \multicolumn{2}{|c|}{$\begin{array}{l}\text { Fiber length } \\
(\mathrm{cm})\end{array}$} & \multicolumn{2}{|c|}{$\begin{array}{l}\text { Fiber fineness } \\
(\mathrm{Nm})\end{array}$} \\
\hline & & $1^{\text {st }}$ & $2^{\text {nd }}$ & $1^{\text {st }}$ & $2^{\text {nd }}$ & $1^{\text {st }}$ & $2^{\text {nd }}$ & $1^{\text {st }}$ & $2^{\text {nd }}$ & $1^{\text {st }}$ & $2^{\text {nd }}$ \\
\hline \multirow{4}{*}{30} & 1500 & 15.97 & 15.57 & 0.325 & 0.302 & 456.16 & 421.50 & 154.17 & 53.85 & 154.17 & 160.40 \\
\hline & 2000 & 17.37 & 16.86 & 0.309 & 0.283 & 574.99 & 524.51 & 172.23 & 61.19 & 172.23 & 178.20 \\
\hline & 2500 & 17.86 & 17.63 & 0.280 & 0.261 & 650.21 & 603.51 & 182.77 & 70.12 & 182.77 & 185.83 \\
\hline & 1500 & 16.80 & 16.18 & 0.402 & 0.371 & 568.00 & 515.52 & 149.17 & 57.87 & 149.17 & 154.67 \\
\hline \multirow[t]{3}{*}{50} & 2000 & 18.30 & 17.86 & 0.386 & 0.359 & 729.43 & 689.30 & 163.27 & 63.66 & 163.27 & 170.60 \\
\hline & 2500 & 18.93 & 18.71 & 0.349 & 0.341 & 816.70 & 795.43 & 175.93 & 73.63 & 175.93 & 180.47 \\
\hline & 1500 & 17.59 & 17.13 & 0.464 & 0.429 & 658.09 & 598.18 & 140.83 & 59.83 & 140.83 & 147.87 \\
\hline \multirow[t]{2}{*}{70} & 2000 & 18.90 & 18.47 & 0.445 & 0.411 & 839.61 & 772.48 & 157.50 & 66.01 & 157.50 & 165.00 \\
\hline & 2500 & 19.55 & 19.40 & 0.408 & 0.378 & 960.57 & 886.00 & 170.93 & 75.86 & 170.93 & 174.63 \\
\hline \multicolumn{2}{|c|}{ L.S.D. at $5 \%$} & N.S. & N.S. & 0.036 & 0.031 & 93.86 & 84.40 & 1.97 & 1.61 & 7.12 & 6.70 \\
\hline
\end{tabular}

Table 17. Mean values of fiber yield and its related traits of flax as affected by interaction between flax cultivar, nitrogen fertilizer rates and plant densities during 2018/2019 $\left(1^{\text {st }}\right)$ and 2019/2020 $\left(2^{\text {nd }}\right)$ seasons.

\begin{tabular}{|c|c|c|c|c|c|c|c|c|c|c|c|c|}
\hline \multirow{2}{*}{$\begin{array}{l}\text { Flax } \\
\text { cultivar }\end{array}$} & \multirow[t]{2}{*}{$\mathrm{N}$ rate } & \multirow{2}{*}{$\begin{array}{l}\text { Plant } \\
\text { density }\end{array}$} & \multicolumn{2}{|c|}{$\begin{array}{c}\text { Total fiber } \\
(\%)\end{array}$} & \multicolumn{2}{|c|}{$\begin{array}{c}\text { Fiber yield/plant } \\
\text { (g) }\end{array}$} & \multicolumn{2}{|c|}{$\begin{array}{c}\text { Fiber yield/fed } \\
(\mathrm{kg})\end{array}$} & \multicolumn{2}{|c|}{$\begin{array}{l}\text { Fiber length } \\
\text { (cm) }\end{array}$} & \multicolumn{2}{|c|}{$\begin{array}{l}\text { Fiber fineness } \\
(\mathbf{N m})\end{array}$} \\
\hline & & & $1^{\text {st }}$ & $2^{\text {nd }}$ & $\mathrm{s}^{\mathrm{st}}$ & $2^{\text {nd }}$ & $1^{\text {st }}$ & $2^{\text {nd }}$ & $1^{\text {st }}$ & $2^{\text {nd }}$ & $1^{\text {st }}$ & $2^{\text {nd }}$ \\
\hline \multirow{9}{*}{ } & \multirow{3}{*}{30} & 1500 & 20.25 & 19.58 & 0.369 & 0.343 & 517.34 & 473.05 & 59.00 & 57.59 & 185.70 & 191.60 \\
\hline & & 2000 & 21.99 & 21.77 & 0.360 & 0.331 & 662.67 & 603.95 & 65.85 & 64.70 & 215.70 & 224.60 \\
\hline & & 2500 & 22.24 & 22.23 & 0.339 & 0.314 & 773.56 & 707.86 & 75.25 & 72.76 & 233.60 & 239.70 \\
\hline & \multirow{3}{*}{50} & 1500 & 21.16 & 20.53 & 0.459 & 0.431 & 655.85 & 589.47 & 63.93 & 60.85 & 180.60 & 186.70 \\
\hline & & 2000 & 23.25 & 22.85 & 0.447 & 0.417 & 855.66 & 827.28 & 69.30 & 66.39 & 200.30 & 213.50 \\
\hline & & 2500 & 23.98 & 23.85 & 0.419 & 0.410 & 973.17 & 952.27 & 80.04 & 74.92 & 225.70 & 230.60 \\
\hline & \multirow{3}{*}{70} & 1500 & 22.01 & 21.99 & 0.518 & 0.509 & 747.07 & 701.37 & 65.60 & 62.94 & 167.20 & 178.30 \\
\hline & & 2000 & 23.66 & 23.17 & 0.517 & 0.463 & 986.74 & 875.36 & 71.74 & 68.29 & 192.50 & 207.40 \\
\hline & & 2500 & 24.34 & 24.23 & 0.492 & 0.449 & 1164.79 & 1051.40 & 83.93 & 78.87 & 220.40 & 225.20 \\
\hline \multirow{9}{*}{ 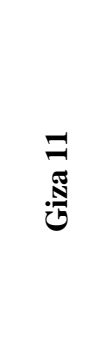 } & \multirow{3}{*}{30} & 1500 & 13.58 & 13.11 & 2 & 0.267 & 413.14 & & 54.69 & 50.11 & 135.60 & 139.80 \\
\hline & & 2000 & 14.89 & 13.93 & 0.275 & 0.244 & 518.66 & 460.77 & 61.64 & 57.53 & 146.70 & 151.30 \\
\hline & & 2500 & 15.44 & 15.1 & 0.244 & 0.227 & 576.07 & 535 & 70.51 & 67.05 & 152 & 155.60 \\
\hline & \multirow{4}{*}{50} & 1500 & 14.22 & 13.65 & 0.356 & 0.327 & 502.89 & 461.30 & 58.19 & 54.10 & 129.70 & 133.60 \\
\hline & & 2000 & 15.67 & 15.19 & 0.343 & 0.318 & 646.74 & 598.56 & 63.67 & 60.82 & 140.20 & 143.60 \\
\hline & & 2500 & 16.2 & 15.8 & & 0.295 & 721.58 & 696.93 & 75.15 & 70.95 & 147 & 151.10 \\
\hline & & 1500 & 14.89 & 14.22 & 0.411 & 0.366 & 578.89 & 516.83 & 60.69 & 55.93 & 123.80 & 129.70 \\
\hline & \multirow[t]{3}{*}{70} & 2000 & 16.31 & 15.88 & 0.390 & 0.373 & 734.03 & 701.66 & 66.26 & 63.01 & 136.80 & 139.70 \\
\hline & & 2500 & 16.99 & 16.82 & 0.353 & 0.333 & 832.13 & 783.77 & 77.43 & 73.13 & 142.70 & 147.50 \\
\hline \multirow{9}{*}{$\frac{\text { I }}{\mathbb{3}}$} & & 1500 & 14.08 & 14.01 & 0.313 & 0.296 & 437.99 & 414.63 & 56.07 & 53.86 & 141.20 & 149.80 \\
\hline & \multirow[t]{2}{*}{30} & 2000 & 15.24 & 14.87 & 0.291 & 0.273 & 543.65 & & 64.80 & 61.34 & 154.30 & 158.70 \\
\hline & & 2500 & 15.89 & & & 0.243 & & & 72.85 & 70.55 & 162.40 & 162.20 \\
\hline & \multirow{3}{*}{50} & 1500 & 15.02 & 14.36 & 0.389 & 0.354 & 545.26 & 495.78 & 61.14 & 58.66 & 137.20 & 143.70 \\
\hline & & 2000 & 15.99 & 15.55 & 0.367 & 0.344 & 685.89 & 642.06 & 67.48 & 63.78 & 149.30 & 154.70 \\
\hline & & 2500 & 16.55 & & 0.324 & 0.316 & & 737.10 & 76.98 & 75.01 & 154.30 & 159.70 \\
\hline & \multirow{3}{*}{70} & 1500 & 15.88 & 15.18 & 0.463 & 0.412 & 648.30 & 576.35 & 63.67 & 60.62 & 131.50 & 135.60 \\
\hline & & 2000 & 16.72 & 16.35 & 0.428 & 0.397 & 798.05 & 740.41 & 68.50 & 66.72 & 143.20 & 147.90 \\
\hline & & 2500 & 17.33 & 17.16 & 0.379 & 0.353 & 884.78 & 822.82 & 78.36 & 75.59 & 149.70 & 151.20 \\
\hline \multicolumn{3}{|c|}{ L.S.D. at $5 \%$} & N.S. & N.S. & 0.063 & 0.054 & 162.57 & 146.19 & 3.42 & 2.79 & 12.33 & 11.61 \\
\hline
\end{tabular}




\section{C- Anatomical manifestations:}

Mean values of different tissues area per cross section at the middle region of stems and fiber index estimates for three flax cultivars as affected by nitrogen fertilizer rates and plant densities treatments during the second season are presented in Table $\mathbf{1 8 .}$ Data illustrated an increase in each of total cross section, cortex, fiber, xylem areas and fiber index per plant in all flax cultivars under study (Sakha 3, Giza 11 and Giza 12) as affected by fertilized flax plants with $70 \mathrm{~kg} \mathrm{~N} / \mathrm{fed}$ and plant density at $1500 \mathrm{seeds} / \mathrm{m}^{2}$. The respective values of these previous characters for Sakha 3 cultivar were 4.91, 0.89, 0.83, $1.57 \mathrm{~mm}^{2}$ and $581.25 \mathrm{~mm}^{3}$, respectively. Meanwhile, Giza 11 cultivar recorded $7.07,1.22,0.77,3.31 \mathrm{~mm}^{2}$ and $512.20 \mathrm{~mm}^{3}$. In addition to $6.38,1.02,0.70,3.06$ $\mathrm{mm}^{2}$ and $470.96 \mathrm{~mm}^{3}$ for Giza 12 cultivar in the same arrangement with mentioned before. But the lowest estimates for these traits which above mentioned were obtained by added $30 \mathrm{~kg} \mathrm{~N} / \mathrm{fed}$ and plant density at $2500 \mathrm{seeds} / \mathrm{m}^{2}$ for the three flax cultivars. Pith area per cross section was slightly greater by using $30 \mathrm{~kg} \mathrm{~N} / \mathrm{fed}$ and highest plant density (2500 seeds $/ \mathrm{m}^{2}$ ). It must be mentioned, that Sakha 3 cultivar achieved highest fiber area per cross section when compared with the other two ones (Giza 11 and Giza 12), meanwhile the latter two cultivars recorded more xylem area per cross section. Added $50 \mathrm{~kg} \mathrm{~N} / \mathrm{fed}$ and plant density of 2000 seeds $/ \mathrm{m}^{2}$ gave intermediate estimates between either $30 \mathrm{~kg} \mathrm{~N} / \mathrm{fed}$ and 2500 seeds $/ \mathrm{m}^{2}$ or $70 \mathrm{~kg} \mathrm{~N} /$ fed and 1500 seeds $/ \mathrm{m}^{2}$. Slight variation between the three flax cultivars under $30 \mathrm{~kg}$ $\mathrm{N} /$ fed with plant density of $2500 \mathrm{seeds} / \mathrm{m}^{2}$ and $70 \mathrm{~kg}$ $\mathrm{N} /$ fed with plant density of $1500 \mathrm{seeds} / \mathrm{m}^{2}$ on the different tissues area cross sections are shown in Figs 1 to 6. The present findings are in accordance with those recorded by El-Shimy et al. 1993; El-Nagdy et al. 2010; El-Gedwy et al. 2018 and El-Shimy et al. 2019.

Percentage of different tissue areas concerning its corresponding total cross section area for three flax cultivars as affected by nitrogen fertilizer rates and plant densities treatments during the second season are presented in Table 19. Results indicated that the treatment of $30 \mathrm{~kg} \mathrm{~N} /$ fed and plant density by 2500 seeds $/ \mathrm{m}^{2}$ achieved highest percentages of fiber and pith $\%$ in all three flax cultivars. It means that more plant density per unit area caused an increment in fiber as resulted from tallest technical stem length and relatively thinner flax plants, consequently more fiber yield with fineness and more pith area which had observed in fiber flax type characteristics. In the same time, cortex and xylem \% took opposite trend, that the treatment of $70 \mathrm{~kg} \mathrm{~N} / \mathrm{fed}$ and plant density of $1500 \mathrm{seeds} / \mathrm{m}^{2}$ which recorded maximum cortex and xylem \% in Sakha 3, Giza 11 and Giza 12. The present findings are in accordance with those recorded by El-Shimy et al. 1993; El-Nagdy et al. 2010; El-Gedwy et al. 2018 and El-Shimy et al. 2019.

Table 18: Mean values of different tissues area per cross section at the middle region of stems and fiber index estimates for three flax cultivars as affected by nitrogen fertilizer rates and plant densities treatments during 2019/2020 season.

\begin{tabular}{|c|c|c|c|c|c|c|c|c|}
\hline $\begin{array}{l}\text { Flax } \\
\text { cultivar }\end{array}$ & $\begin{array}{c}\text { N rate } \\
(\mathrm{kg} / \mathrm{fed})\end{array}$ & $\begin{array}{c}\text { Plant } \\
\text { density } \\
\left(\operatorname{seeds} / \mathbf{m}^{2}\right) \\
\end{array}$ & $\begin{array}{c}\text { Total cross } \\
\text { section area } \\
\left(\mathrm{mm}^{2}\right)\end{array}$ & $\begin{array}{l}\text { Cortex area } \\
\quad\left(\mathbf{m m}^{2}\right)\end{array}$ & $\begin{array}{c}\text { Fiber area } \\
\left(\mathbf{m m}^{2}\right)\end{array}$ & $\begin{array}{c}\text { Xylem } \\
\left(\mathbf{m m}^{2}\right)\end{array}$ & $\begin{array}{l}\text { Pith } \\
\left(\mathbf{m m}^{2}\right)\end{array}$ & $\begin{array}{c}\text { Fiber } \\
\text { index/plant } \\
\left(\mathbf{m m}^{3}\right)\end{array}$ \\
\hline \multirow{3}{*}{ Sakha 3} & 30 & 2500 & 4.23 & 0.63 & 0.78 & 1.14 & 1.68 & 546.23 \\
\hline & 50 & 2000 & 4.52 & 0.74 & 0.80 & 1.40 & 1.58 & 560.24 \\
\hline & 70 & 1500 & 4.91 & 0.89 & 0.83 & 1.57 & 1.62 & 581.25 \\
\hline \multirow{3}{*}{ Giza 11} & 30 & 2500 & 5.38 & 0.60 & 0.69 & 2.31 & 1.78 & 458.99 \\
\hline & 50 & 2000 & 6.15 & 0.93 & 0.74 & 2.73 & 1.75 & 492.25 \\
\hline & 70 & 1500 & 7.07 & 1.22 & 0.77 & 3.32 & 1.76 & 512.20 \\
\hline \multirow{3}{*}{ Giza 12} & 30 & 2500 & 5.06 & 0.61 & 0.62 & 2.13 & 1.70 & 417.14 \\
\hline & 50 & 2000 & 5.34 & 0.75 & 0.65 & 2.28 & 1.66 & 437.32 \\
\hline & 70 & 1500 & 6.38 & 1.02 & 0.70 & 3.06 & 1.60 & 470.96 \\
\hline
\end{tabular}

Table 19. Percentage of different tissue areas concerning its corresponding total cross section area for three flax cultivars as affected by nitrogen fertilizer rates and plant densities treatments during 2019/2020 season.

\begin{tabular}{|c|c|c|c|c|c|c|}
\hline $\begin{array}{c}\text { Flax } \\
\text { Cultivar }\end{array}$ & $\begin{array}{c}\text { N rate } \\
(\mathrm{kg} / \mathrm{fed})\end{array}$ & $\begin{array}{c}\text { Plant density } \\
(\text { seeds/m²) }\end{array}$ & $\begin{array}{c}\text { Cortex } \\
\% \\
\end{array}$ & $\begin{array}{c}\text { Fiber } \\
\% \\
\end{array}$ & $\begin{array}{c}\text { Xylem } \\
\%\end{array}$ & $\begin{array}{c}\text { Pith } \\
\%\end{array}$ \\
\hline \multirow{3}{*}{ Sakha 3} & 30 & 2500 & 14.89 & 18.44 & 26.95 & 39.72 \\
\hline & 50 & 2000 & 16.37 & 17.70 & 30.97 & 34.96 \\
\hline & 70 & 1500 & 18.13 & 16.90 & 31.98 & 32.99 \\
\hline \multirow{3}{*}{ Giza 11} & 30 & 2500 & 11.15 & 12.83 & 42.94 & 33.09 \\
\hline & 50 & 2000 & 15.12 & 12.03 & 44.39 & 28.46 \\
\hline & 70 & 1500 & 17.26 & 10.89 & 46.96 & 24.89 \\
\hline \multirow{3}{*}{ Giza 12} & 30 & 2500 & 12.06 & 12.25 & 42.09 & 33.60 \\
\hline & 50 & 2000 & 14.04 & 12.17 & 42.70 & 31.09 \\
\hline & 70 & 1500 & 15.99 & 10.97 & 47.96 & 25.08 \\
\hline
\end{tabular}



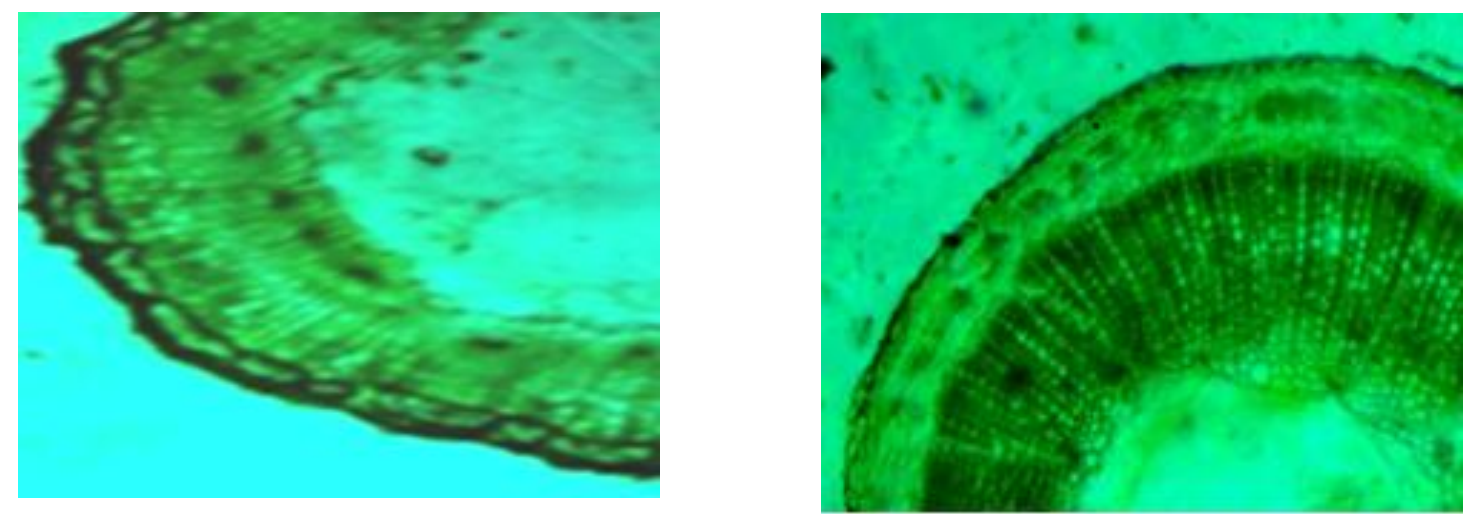

Fig 1: Cross section in the middle region at full maturity Fig 2: Cross section in the middle region at full maturity of Sakha $3 \mathrm{cv}$. with soil fertilized by $30 \mathrm{~kg} \mathrm{~N} / \mathrm{fed}$ and plant of Sakha $3 \mathrm{cv}$. with soil fertilized by $70 \mathrm{~kg}$ N/fed and plant density of $2500 \mathrm{seeds} / \mathrm{m}^{2}$

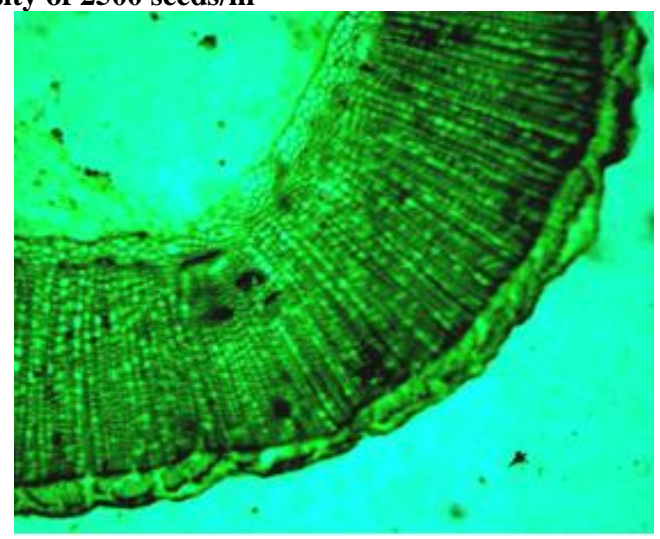
density of $1500 \mathrm{seeds} / \mathrm{m}^{2}$

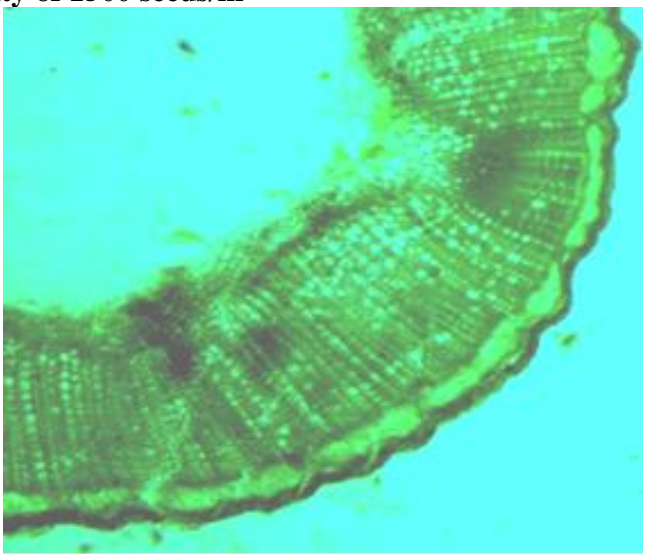

Fig 3: Cross section in the middle region at full maturity Fig 4: Cross section in the middle region at full maturity of Giza $11 \mathrm{cv}$. with soil fertilized by $30 \mathrm{~kg} \mathrm{~N} / \mathrm{fed}$ and plant of Giza $11 \mathrm{cv}$. with soil fertilized by $70 \mathrm{~kg}$ N/fed and plant density of $2500 \mathrm{seeds} / \mathrm{m}^{2}$

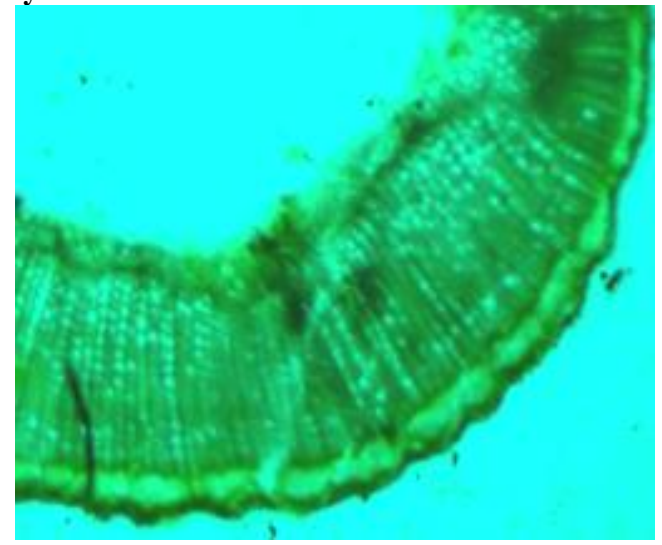
density of $1500 \mathrm{seeds} / \mathrm{m}^{2}$

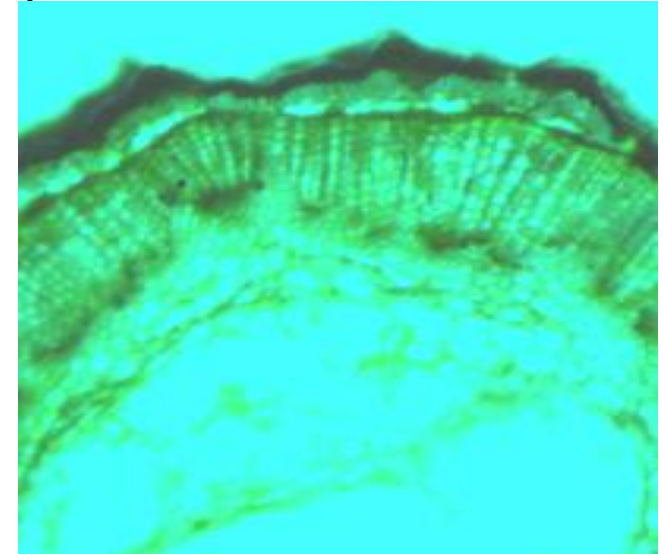

Fig 5: Cross section in the middle region at full maturity Fig 6: Cross section in the middle region at full maturity of Giza $12 \mathrm{cv}$. with soil fertilized by $30 \mathrm{~kg} \mathrm{~N} / \mathrm{fed}$ and plant of Giza $12 \mathrm{cv}$. with soil fertilized by $70 \mathrm{~kg} \mathrm{~N} / \mathrm{fed}$ and plant density of $2500 \mathrm{seeds} / \mathrm{m}^{2}$ density of $1500 \mathrm{seeds} / \mathrm{m}^{2}$

\section{Conclusion:}

From the obtained results of this study it could be concluded that Sakha 3 cultivar and fertilizing by 70 $\mathrm{kg} \mathrm{N} / \mathrm{fed}$ with plant density of $2500 \mathrm{seeds} / \mathrm{m}^{2}$ achieved maximum fiber yield/fed and quality.

\section{Acknowledgement}

The authors thank Prof. Dr. Gamal El-Din ElShimy Head Researcher in Fiber Crops Res. Sec., Field Crops Res. Inst., Agric. Res. Center, Giza,
Egypt, for reviewing and helpful comments regarding a previous draft of the manuscript.

\section{References}

Abd Eldaiem, M. A. M. (2015). Response of some flax genotypes under different plant densities. J. Plant Production, Mansoura Univ., 6 (7): 1247 1261. 
Abd El-Mohsen, A. A.; A. M. Abdallah and G. O. Mahmoud (2013). Optimizing and describing the influence of planting dates and seeding rates on flax cultivars under Middle Egypt region conditions. J. Appl. Sci. Res., 9 (7): 4174-4185.

Abdel-Kader, E. M. A. and A. M. A. Mousa (2019). Effect of nitrogen fertilizer on some flax varieties under two different location conditions. J. Plant Production, Mansoura Univ., 10 (1): 3744.

Ahmed, R. H. H. (2010). Effect of mineral fertilization and plant density on some flax varieties under sandy soil conditions. M. Sc. Thesis, Agron. Depart., Fac. Agric., Cairo Univ., Egypt.

Andruszczak, S.; U. Gawlik-Dziki; P. Kraska; E. Kwiecińska-Poppe; K. Różyło and E. Pałys (2015). Yield and quality traits of two linseed (Linum usitatissimum L.) cultivars as affected by some agronomic factors. Plant Soil Environ., 61 (6): 247-252.

El-Borhamy, A. M. A. (2016). Effect of seeding rates and nitrogen fertilizer levels on yield and yield components of two new flax cultivars. J. Agric. Res. Kafr El-Sheikh Univ., 42 (2): 183195.

El-Gedwy, E. M. M.; G. Y. M. Hammam; S. A. H. Allam; S. H. A. Mostafa and Kh. S. S. ElShimy (2018). Effect of irrigation intervals and nitrogen fertilizer rates on flax yield and some anatomical manifestations. Menoufia J. Plant prod., 3 (1): 1-19.

El-Nagdy, G. A.; D. M. A. Nassar; E. A. El-Kady and G. S. A. El-Yamanee (2010). Response of flax plant (Linum usitatissimum L.) to treatments with mineral and bio-fertilizers from nitrogen and phosphorus. J. American Sci., 6 (10): 207:217.

El-Refaey, R. A.; E. H. El-Seidy; T. A. AbouZaied; U. A. Abd El-Razek and E. A. Rashwan (2015). Effect of different mineral and biological nitrogenous fertilizers combinations on straw yield and fiber quality of some flax 'Linum usitatissimum L.' genotypes. Glob. J. Agric. Food Safety Sci., 2 (3): 161-179.

El-Shimy, G. H.; A. M. M. El-Refaie and M. S. Abd Al-Sadek (2019). Yield, Genetic parameters, correlation and anatomy for some flax genotypes. Egypt. J. Plant Breed. 23 (8):1647-1668.

El-Shimy, G. H.; E. A. F. El-Kady and N. K. M. Mourad (1993). Effect of seeding rates and nitrogen levels on yield and anatomical manifestations of some flax genotypes. J. Agric. Res. Tanta Univ., Egypt. 19 (1): 92-104.

El-Shimy, Kh. S. S.; G. Y. M. Hammam; S. A. H. Allam; S. H. A. Mostafa and El. M. M. ElGedwy (2017). Flax yield potential as affected by irrigation intervals and nitrogen fertilizer rates. Annals of Agric. Sci., Moshtohor, 55 (4): 817824.
Emam, S. M. (2019). Effectiveness of sowing dates and $\mathrm{N}$ rates on productivity of two flax (Linum usitatissimum L.) cultivars. Egypt. J. Agron., 41 (3): 261-274.

Emam, S. M. (2020). Estimation of straw, seed and oil yields for flax plants (Linum usitatissimum L.) cultivars of foliar application of $\mathrm{Mn}, \mathrm{Fe}$ and $\mathrm{Zn}$ under dry environment. Egypt. J. Agron., 42 (1): 35-46.

Fila, G.; M. Bagatta; C. Maestrini; E. Potenza and R. Matteo (2018). Linseed as a dual-purpose crop: evaluation of cultivar suitability and analysis of yield determinants. J. Agric. Sci., 156 (2): 162-176.

Freed, R. D. (1991). MSTATC Microcomputer Statistical Program. Michigan State University, East Lansing, Michigan, USA.

Ganvit, J. B.; S. Sharma; V. H Surve and V. C. Ganvit (2019). Effect of sowing dates and crop spacing on growth, yield and quality of linseed under south Gujarat condition. J. Pharm. Phytoch., 8 (1): 388-392.

Gomez, K. A. and A. A. Gomez (1984). Statistical procedures for agricultural research. $2^{\text {nd }}$, (ed). John Wiley and Sons, NY, U.S.A.

Gupta, M.; S. Kour; V. Gupta; R. Bharat and C. Sharma (2017). Effect of different doses of fertilizers on yield and NPK uptake of linseed (Linum usitatissimum L.). Bangladesh J. Bot., 46 (2): 575-581.

Ibrahim, M. H.; M. E. Kineber; A. Y. Ragab and W. F. M. A. Galoo (2016). Impact of nitrogen fertilizer level and times of foliar spraying with potassium on yield and its components of some flax genotypes. J. Agric. Res. Kafr El-Sheikh Univ., 42 (4): 580-598.

Johanson, D. V. (1940). Plant microtechnique. New York and London, McGrow-Hill Book Co. INC, 27-154.

Omar, A. E. A. and S. M. A. I. Ash-Shormillesy (2006). Effect of seeding rate and nitrogen fertilization on the yield of flax. J. Product. \& Dev., 11 (2): 337-350.

Radwan, S. R. H. and A. Momtaz (1966). The technological properties of flax fibers and the methods of estimating them. El- Falaha J., 46 (5):466-476.

Rowell, D. L. (1995). Soil science methods and applications. Library of Congress Cataloging Publication Data. New York. NY 10158. USA.

Sass, J. E. (1951). Botanical microtechnique. Iowa State College Press, Ames, Iowa, 228.

Teshome, M.; D. Tadesse and Y. Ousman (2020). Effects of seed rates and row spacing on yield and yield components of linseed (Linum usitatissimum L.) at Dabat district of North Gondar Zone, Ethiopia. J. Appl. Biotechnol. Bioeng., 7 (1):1-5. 
تأثير الكثافة النباتية و معدلات السماد النيتروجيني على محصول القش، الألياف و الصفات التشريحية لبعض أصناف الكتان

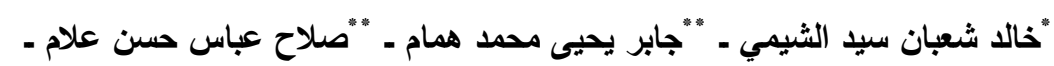

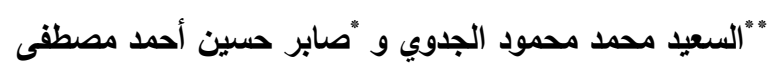

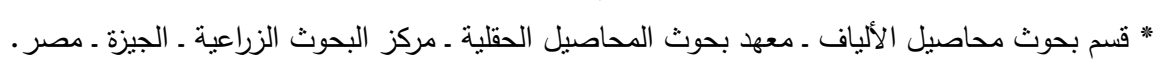

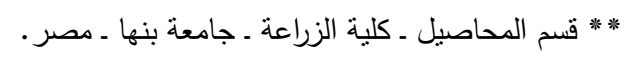

أجريت تجربتان حقليتان في مزرعة محطة البحوث الزراعية بالجميزة ـ محافظة الغربية ـ مركز البحوث الزراعية ـ مصر ـ خلال الموسمين

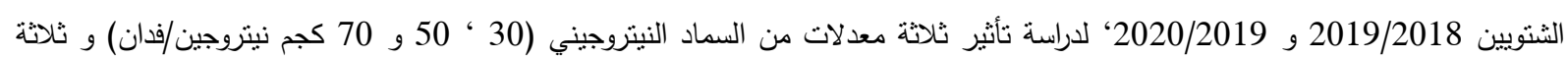

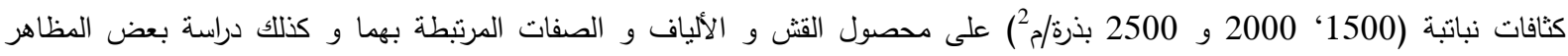

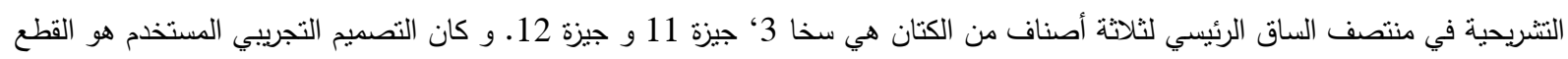

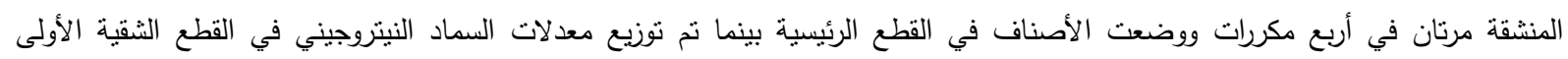

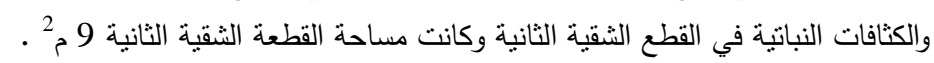
الإختلافات بين أصناف الكتان تحت الدراسة كانت معنوية في جميع الصفات الددروسة لدحصول القش و الألياف و الصفات المرتبطة بهما

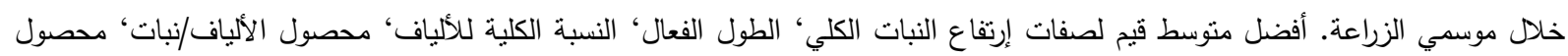

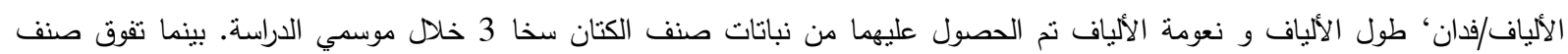

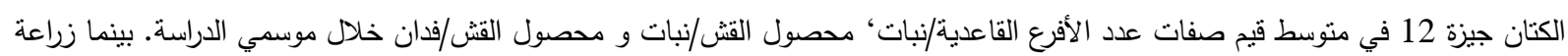
صنف الكتان جيزة 11 أنتج معنوياً أغلظ سيقان للكتان خلان فئل موسمي الدراسة.

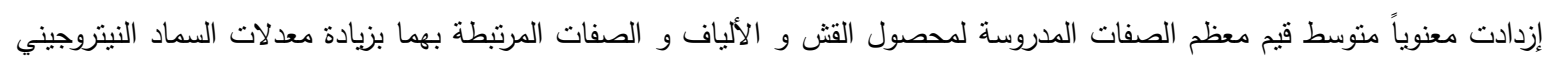

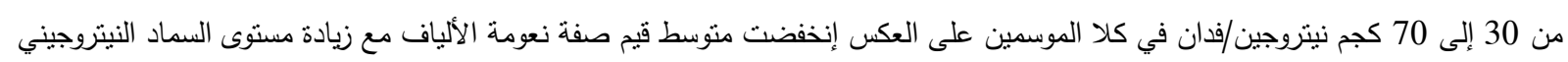

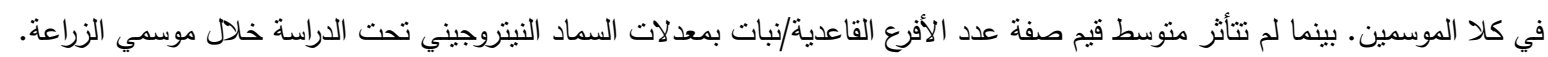

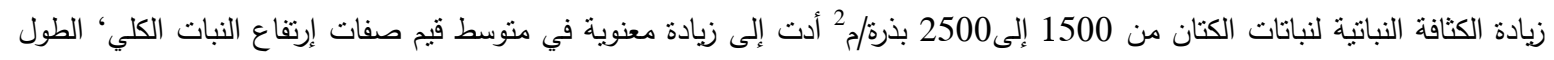

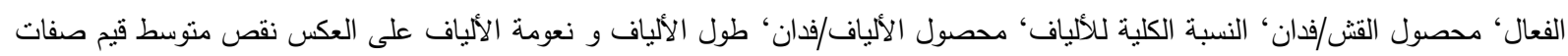

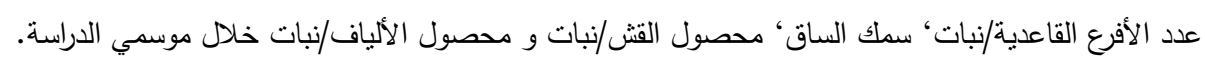

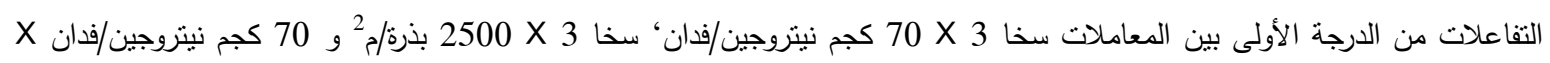

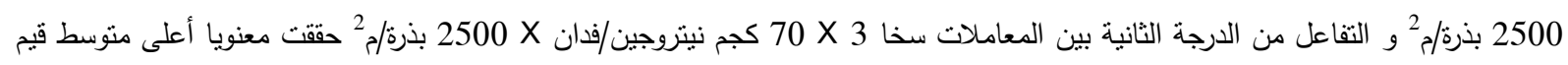

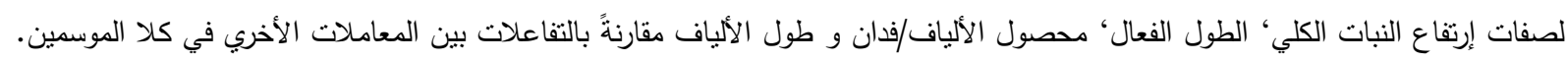

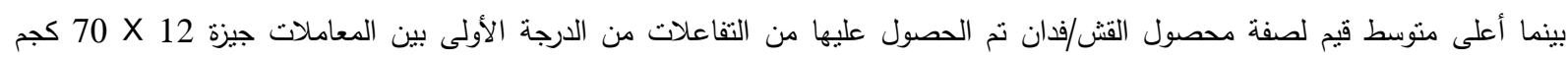

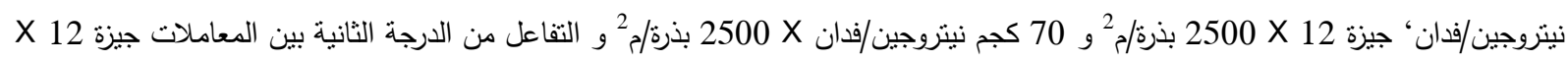

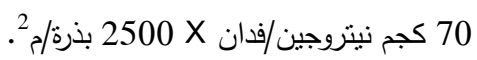
أشثارت الننائج حدوث زيادة في كل من المقطع العرضي الكلي للساق، مساحة القشرة' مساحة الألياف، مساحة الخشب، دليل الألياف/نبات،

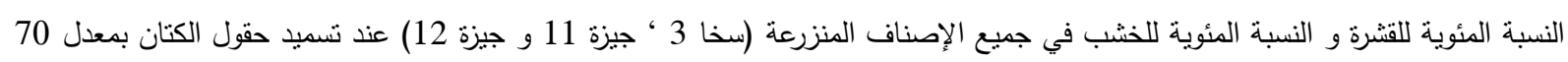
كجم نيتروجين/فدان و زراعتها بكثافة نباتية 1500 بذرة/2².

الخلاصة:

نوصي النتائج بزراعة الكتان صنف سخا 3 مع التسميد النيتروجيني بمعدل 70 كجم نيتروجين/فدان عند كثافة نباتية 2500 بذرة/م²حيث عظت إنتاجية محصول الألياف بوحدة المساحة. 